\title{
Ansiklopedist Bir Düşünür Olarak Roger Bacon
}

\section{Ahmet Erhan ŞEKERCi*}

\section{Roger Bacon as an Encyclopedist}

Citation/C: Şekerci, Ahmet Erhan, (2014). Ansiklopedist Bir Düşünür Olarak Roger Bacon, Milel ve Nihal, 11 (2), 103-138.

Abstract: Roger Bacon came into sight in the scene of history in the last half of 13th century, at an epoch when Christian dogmatism and Scholastic thought were unchallenged. The main focus of this article is Bacon's views on innovation and science that have paved the way for the Scientific Revolution, as they also inspired the pioneers of the modern thought. Although he is not as famous and successful as St. Thomas and Albertus Magnus in terms of intellectual life, he was far-sighted and more influential. He expressed himself in the same encyclopédiste manner with Aristotle, a philosopher whom Bacon was very fond of. We are going to deal with this crucial figure of the Western thought in depth and while the details of his intellectual life will be threshed out.

Key Words: Science, Classical Languages, Alchemy, Astrology, Education, Mathematics, Scholastic Thought, Avicenna, Ibn al-Haytham, Batlamyus.

Atıf/C: Şekerci, Ahmet Erhan, (2014). Roger Bacon as an Encyclopedist, Milel ve Nihal, 11 (2), 103-138.

Öz: Makalemizde Hıristiyan dogmatizminin en yoğun ve skolastik düşüncenin en kuvvetli olduğu 13. yüzyılın ilk yarısında düşünce dünyasına giren Roger

* Yard. Doç. Dr., İstanbul Üniversitesi, İlahiyat Fakültesi, Felsefe Tarihi Anabilim Dalı [ahmetsekerci@gmail.com] 
Bacon'ın, değişime ve bilime dair çabalarını ele almaya çalışacağız. 0, bilime ve felsefi düşünceye olan yaklaşımıyla, Ortaçağ Hıristiyan dünyada yavaş yavaş etkisini göstermeye başlayan düşünsel değişimin müjdecisi ve Yeniçağın ilham kaynağı olmuş bir düşünürdür. Çağdaşları olan St. Thomas ve Albertus Magnus gibi çok popüler ve başarılı bir düşün hayatı geçirmese de, onlardan daha ileri bir vizyona ve bilim anlayışına sahiptir. Sahip olduğu görüşleri, hayranı olduğu Aristo gibi ansiklopedist bir tarzda ortaya koymuştur. Biz de bu makalemizde düşünürün genel portresinin yanında, onun vizyoner yapısını da ortaya koyan, ansiklopedist yönünü ele alacağız.

Anahtar Kelimeler: Bilim, Klasik Diller, Simya, Astroloji, Eğitim, Matematik, Skolastik Düşünce, İbn Sina, İbn Heysem, Batlamyus.

\section{Giriş}

XIII. yüzyıl düşünce tarihi bakımından en önemli dönüm noktalarından birini teşkil etmektedir. Doğu dünyasında İslam Düşüncesi en parlak günlerini yaşarken, Batı'da Skolastik düşüncenin mutlak bir hâkimiyetinin olduğu farklı bir tecrübe yaşanmaktaydı. Bu dönem, Müslümanlar için ne kadar parlak ise, Batılılar için de o kadar karanlık ve dogmatik bir zaman dilimini ifade ediyordu. XIII. yüzyıl aynı zamanda Batı Düşüncesi bakımından büyük bir düşünsel kırılmanın başladığ 1 bir dönemdir. Tercüme faaliyetleriyle başlayan bilgisel aktarım daha sonra, Rönesans, Reform ve Aydınlanmayla ivme kazanıp sanayi devrimiyle gücünü artırmış ve Modern Avrupa'nın temelleri atılmıştır. Her medeniyetin kendini tanımladığı ve ilham aldığ 1 düşünürler olmuştur. Felsefi düşünceyi kendine rehber edinen her topluluk, dünyanın ilk sistem filozofları olan Platon ve Aristo'ya bu bağlamda çok önem vermiştir. İdealist dünyanın parlayan yıldızı olan Platon'un yanında, onun öğrencisi olan Aristo'nun bilimci kişiliği felsefenin öğretilebilir kılınmasını sağlamıştır. Bilimci kişiliğiyle ön plana çıkan Aristo'nun en önemli yönü ise kuşkusuz onun önemli bir ansiklopedist oluşudur. Bu yüzdendir ki hala yapılan her çalışmada az ya da çok ona referans yapılma ihtiyacını duymaktayız. Ondan yaklaşık 15 asır sonra İngiltere'de dünyaya gelen Bacon, ortaya koyduğu görüşler ve ansiklopedist tavrıyla, Batı dünyasında başlamakta olan dönüşümün ilk neferlerinden ve değişimin ilham kaynaklarından birisi olmuştur. Gerçi o hiçbir zaman Aristo gibi büyük bir filozof ve ansiklopedist olamamıştır ama içinde yaşadığı Skolastik ortamı ve gördügü baskı ve ötekileştirmeyi de dikkate aldığımızda onun öngörülerinin zamanına göre dikkate değer olduğunu söylemek hakkaniyetli olacaktır. Henüz tam bir bilim felsefesinden bahsetmenin çok erken olduğu Batı 
dünyasında ortaya koyduğu görüşler, kendinden sonra gerçekleşen bilimsel gelişmelere de temsili bir katkı sağlamıştır. XVI. yüzyılla başlayıp günümüze kadar süren Batı merkezli düşünce dünyasının merkezinde, bilim felsefesinin ürettiği somut ürün ve veriler vardır. Rasyonalizm ve ampirizmle yeniden kendine çekidüzen veren felsefe, aydınlanmayla beraber artık toplumsal bir gerçeklik haline dönmüştür. Bu gerçekliğin temelinde ona rengini veren şey onu üreten medeniyet ve coğrafyadır. Günümüz Batı medeniyetini anlamak için, onu bu günlere getiren süreçleri ve düşünürleri iyi bilmek ve analiz etmek gerekmektedir. Bu düşünürlerden birisi olan Roger Bacon, yaşadığı siyasi ortamı ve entelektüel düzeyi iyi analiz etmiş bir filozof olarak bu makalemizin konusunu oluşturmaktadır. O mensubu olduğu düşünce dünyasını eleştirirken, bazen hakkaniyetli bir şekilde Doğu düşünce sistemlerine ve İslam Düşüncesine de önemli vurgular yapmıştır. İslam Düşüncesinden yoğun tercümelerin ve aktarımların yapıldığı bir dönem olan XIII. yüzyıl Batı dünyası, dogmatik düşüncenin en önemli temsilcileri olan Albertus Magnus (ö.1280) ve Thomas Aquinas'ın (ö.1274) yanında, bilimci ve ansiklopedist görüşleriyle kendine yer açmaya çalışan Roger Bacon'da entelektüel dünyaya armağan etmiş bir dönemdir. Biz bu makalemizde Bacon'ın bilimci ve ansiklopedist yönünü ortaya koymaya çalışacağız. Bunu tam olarak başarabilmek için de düşünürün yaşamını ve eserlerini de biraz genişçe ele aldık. Zira bize göre, Batı Düşüncesinde yaşanan entelektüel ve sosyal değişimin boyutunun ve değerinin anlaşılabilmesi bakımından, düşünürün hayatı ve eserleri oldukça önemli bir örneklik teşkil etmektedir.

\section{Hayatı}

Ölümünden sonra "Doctor Mirabilis" (muhteşem doktor) olarak anılan Roger Bacon (öl.1292), on üçüncü yüzyılın ilk çeyreğinde, 1214 yilında İngiltere Somerset, Ilchester'de doğdu. Nispeten zengin bir aileye mensup olan düşünürün, henüz on üç yaşındayken Oxford Üniversitesi'ne kaydolduğu söylenmektedir. Bacon'ın düşünce hayatı boyunca çok özel bir yere sahip olan Oxford, onun eğitime başladığı, hoca olarak uzun yıllar yurtdışında bulunduktan sonra yaşadığı zorluklara karşın kurtuluşu aradığı bir sığınak, bir ilim merkezi ve eviydi.

Klasiklere olan düşkünlüğü, onun genç bir araştırmacıyken Paris'e gitmesine neden olmuştu. XIII. yüzyılın ilk çeyreğinde henüz genç bir üniversite olan Oxford'a nazaran daha iyi imkânlara sahip 
Paris Üniversitesi, o zamanlar tüm Avrupa'dan ilim adamlarını ve araştırmacıları kendine çekmekteydi. Aristo'nun (m.ö. 322) mantık dışında diğer bazı kitaplarının okutulduğunu duyduğu derslere katılmak için gittiği Paris Üniversitesi'nde, ilk önceleri bir ilim gönüllüsüyken, sonraları burada doktorasını ${ }^{1}$ tamamlayıp uzun yıllar sürecek hocalık kariyerine başlamıştır. Bu ilk dönem derslerinde genellikle Aristo'nun tabiat felsefesi ve metafizik eserleri üzerinde durmuş, özellikle de gramer ve mantığa dair dersler vermiştir. Düşünür hem Aristo'nun kendi eserlerine hem de ona nispet edilen eserlere dair yazılar yazmıştır. Onun Aristo üzerine dersler vermesiyle beraber, kullandığı metinler ve ilgisinden dolayı, İslam Düşüncesinin önemli Aristo yorumcularından İbn Rüşd (ö.1198) ve İbn Sina (ö.1037) ile aynı yolu takip ettiğine dair yorumlarla karşılaşmak mümkündür. Kendisi Latin İbn Rüşdçügü içinde yer almasa da, bu çevrede ele alınan çoğu konuyu kendi felsefi alanında da değerlendirmeye çalışmış birisidir; 1240 yılların başında başlayan klasiklere olan düşkünlüğü $1248^{\prime}$ den sonra dile ve sonra da deneysel bilimlere yönelmesine vesile olmuştu. Bu süre zarfında kaleme aldığı en önemli çalışması Grek ve İbranice gramerine dair yazdığı eserdir. ${ }^{2}$ Onun klasiklere, sonrasında ise dile olan düşkünlüğü, eğitim ve reform düşüncesiyle birleşip diğer klasik dilleri de içeren bir tutkuya dönüşmüştür. Aristo tercümelerinin geldiği Arap dili ve bu dilde yazan pek çok Müslüman düşünür onun ilgisini çekmekteydi. Bu ilgi ve merakın sonucunda kendisinin de sıklıkla bahsettiği Müslüman düşünürlerden oldukça etkilenmiş ve Arapça'nın da mutlaka öğretilmesi gereken bir dil olduğunu beyan etmiştir.

1 Roger Bacon'ın teoloji alanında doktor olduğuna dair bilgiler olmakla beraber bazı araştırmacılar bunun şüpheli olduğunu ve hatta hiçbir zaman bu alanda doktor olmadığı iddia etmişlerdir. Özellikle Bacon'ın bilim anlayışı üzerine çalışan Stewart C. Easton'a göre o hiçbir zaman teoloji doktoru olmadığı gibi başka bir doktora payesi de almamıştır. Düşünür hakkında kullanılan “Doktor Mirabilis" lakabı ölümünden sonra kendisini taltif için kullanılan, zamanla yerleşmiş bir deyimdir. Bkz, John Henry Bridges, The Life and Work of Roger Bacon, William and Norgate, London-1914, s.25; A.G. Little, "Introduction: On Roger Bacon's Life and Works", Roger Bacon Essays, Ed. A.G. Little, Oxford University Press, Oxford-1914, s.6; Stewart C. Easton, Roger Bacon and His Search for A Universal Science, Colombia University Press, Newyork-1952, s.19.

2 Bu döneme dair (1237-47) dair diğer iki önemli eseri ise Summa Dialectices ve Summa Grammatica'dır. Bkz, Georgette Sinkler, "Roger Bacon” Routledge Encyclopedia of Philosophy, General Ed. Edward Craig, vol.1, Routledge, New York, 1998 , s.633 
Bacon için hayatının kuşkusuz en önemli dönüm noktası 1256 yılında, kendi çalışmaları bakımından önemli bir fırsat oluşturacağını düşündüğü, Fransisken ${ }^{3}$ tarikatına girmesidir. Tarikata girdiği ilk yıllarda kısmen tanınmış ve iyi bir kariyere sahip genç bir düşünür olarak kabul görmüş; ilk dönemleri de gayet verimli geçirmiştir. Ama düşünürün Fransiskenlik macerası hayatının sonlarına doğru, kendisini hiç ummadığı bir baskı ve ötekileştirmeye maruz bırakacaktır. Çağdaşı olduğu Thomas Aquinas (ö.1274) ve Albertus Magnus (ö.1280) gibi düşünürlere sağlanan imkânların kendisine de sağlanacağını uman Bacon'ın, özellikle o dönem açısından anlaşılması oldukça zor ve bazı yönlerden teolojik problemleri de doğurması muhtemel bilimsel çalışmaları için, umduğu desteği tarikatından bulamamıştı. Tarikata girdikten kısa bir süre sonra kendisinden hoşnut olmayanlar seslerini yükseltmeye başlamışlar ve çalışmalarına kısmi bir sansür uygulamışlardı. Tarikata girdiği yıllarda mistik eğilimleri ağır basan ve Bacon'un ilgi alanlarından oldukça uzak bir mecrada fikir serdeden Bonaventura (John of Fidanza) (ö.1274) tarikata başkanlık yapıyordu. Ancak Bacon açısından işlerin karmaşaya dönüşmeye başladığı dönem, sonradan Papa da olacak olan (IV. Nicholas) Jerome Ascoli'nin (ö.1292) tarikatın başına geçmesiyle başlamıştır. Baskının iyiden iyiye arttığı bir sırada hayatının en anlamlı ve önemli fırsatı ile karşılaşmıştır. Yazılarından ve görüşlerinden haberdar olan Papa IV. Clement (ö.1268) gizlice kendisine haber göndererek eserlerini olabildiğince huzlı bir şekilde kendisine iletmesini istemiştir. Papa'nın kendisine olan bu teveccühünü duyan Fransiskenler'in ona olan baskısı azalmış; ancak bakış açıları daha da olumsuz bir noktaya evrilmiştir. Papa'nın zımni koruması altına giren Bacon, IV. Clement'in ölümüne değin çok üretken üç yıl geçirmiştir. Sırasıyla onun en önemli eserleri olarak kabul edilen ve çalışmamızın başlığında ifade ettiğimiz ansiklopedist tanımlamasının oluşmasında etkili olan ünlü eserleri Opus 
Majus, Opus Tertium ve Opus Minus'u yazıp, Papa IV. Clement'e göndermiştir. ${ }^{4}$ Papa'ya göndermeyi tasarladığ 1 Opus Principale adındaki eserini ise tamamlayamamıştır. 1266-68 yılları arasında sırasıyla yazdığı bu eserlerden Opus Tertuim ve Opus Minus ilk eseri tamamlamak ve ortaya çıkan soruları izale etmek için yazılmış eserlerdir. ${ }^{5}$ Üç yıl gibi kısa bir süre papalık yapan IV. Clement'in 1268 yılında hayatını kaybetmesiyle beraber Bacon için gerçekten zorlu bir süreç başlamıştır. IV. Clement'in etkisiyle yazmaya devam eden düşünür, sonrasında da özellikle bilimsel alanlarda yazılar yazmıştır. Astronomi/astroloji, ilaç, simya/kimya, optik, tabiat bilimleri gibi çok geniş bir alanda yazılar yazmış, görüşlerini ortaya koymuştur. Özellikle astroloji ve simya gibi insanlık için her zaman gizemli olarak kabul edilen alanlarda yazdığı yazılar, hakkında okkült/gizemli eğilimlerinin olduğuna dair kanıların oluşmasında etkili olmuştur. Kendisi üzerindeki baskıların da dayanak noktasını oluşturan bu eğilimler, kendisinin büyü ve sihir ile uğraştığı hakkında dedikodular çıkmasına, sakıncalı görüşler ortaya koyduğuna dair kanaatlerin oluşmasına sebep olmuştur. 1277 yılı onun hayatı açısından başka bir dönüm noktasıdır. ${ }^{6}$ Yıllardır içinde bulunduğu Paris Üniversitesi'ndeki felsefi ve teolojik tartışmalardan yorulmuş; gerek hocalarla ve gerekse yöneticilerle ters düşmüştür. Bu nedenle Paris Piskoposu, Papa'nın emri ile hakkında soruşturma başlatmıştır. Kendisine özellikle gizem ve büyü üzerinden pek çok suç isnat edilmiştir. Bu suçlamalardan önemli bir kısmı da astroloji hakkındadır. Astrolojik olarak yıldızlara yüklemlenen geleceğe hakkındaki haberler, özellikle de yaşam, ölüm, hastalık gibi durumlara dair düşünceleri kendisine sorulmuştu. ${ }^{7}$ Bahsi geçen suçlamalar tam olarak

4 George Sarton, Introduction to the History of Science From Rabbi Ben Ezra to Roger Bacon, vol.II, New York-1975, s.953

5 Eserlerle ilgili geniş bilgi, yazımısın eserler başlığı altında verilecektir.

6 Bu yıllar Latin İbn Rüşdçülüğünün Avrupa'da etkin olduğu ve müteakiben yasaklanmaya başladığı dönemlerle kesişmektedir. 1277 yılında Stephen Tempier'in İbn Rüşdçülüğü mahkum etmesiyle birlikte, zaten Fransiskenler daha da sert tutum sergilemeye başlamışlardı. İbn Rüşdçülüğü ve dolayısıyla Aristocu geleneği derslerinde işleyen Bacon için bu durum ayrıca bir problem kaynağıdır. Onun kovuşturmaya uğrama nedenlerinden bir tanesi de bu olsa gerektir. Bkz, George Sarton, Introduction to the History of Science From Rabbi Ben Ezra to Roger Bacon, vol.II, s.953

7 Bkz, A.G. Little, Introduction: “On Roger Bacon's Life and Works”, Roger Bacon Essays, s.23, 24 
ispat edilmeden, Jerome Ascoli'nin de baskısıyla, bir anlamda şüpheli konumuna binaen hapse mahkûm edilmiştir. Hapis hayatı, düşünürün hapse mahkûm edilmesinde önemli bir faktör olan IV. Nicholas'ın (Jerome Ascoli)'nin 1292 yılında vefat etmesiyle son bulmuştur. Toplamda on dört yıl gibi uzun bir süre hapiste kalan düşünürün hakkındaki suçlamalar, hapse girmesinden hemen sonra, Fransiskenlerin başına geçen Raymund Gaufredi (ö.1310) tarafından 1278 yılında kaldırılmıştır. ${ }^{8}$ Ama Papa'nın zımni baskısından dolayı hapis hayatının bitirilmesi ancak Papa'nın ölümü sonrasında mümkün olmuştur. 1292 yılında kurtulduğu hapis hayatı sonrasinda, doğduğu topraklara, Oxford'a dönen düşünür son eseri olan Compendium Studii Theologiae'yi tamamladıktan hemen sonra, baz1larına göre aynı yıl bazılarına göre iki yıl sonra, 1294 yılında Oxford'da vefat etmiş ve Oxford Fransisken kilisesinin bahçesine defnedilmiştir. ${ }^{9}$

\section{Eserleri}

Roger Bacon'ın hayatı, bazı kısa seyahatleri haricinde genellikle Oxford-Paris arasında geçmiştir. Eserlerinin çoğunluğunu bu şehirlerde, ya üniversitede hocayken ya da serbest çalışırken vermiştir. Düşünürün yaşamış olduğu çalkantılı hayat ve talihsizlikler eserlerini de bir anlamda takip etmiştir diyebiliriz. Zira düşünürün kendi eserleri hakkında şu ana kadar kâmil bir bilgiye sahip olmadığımız gibi, ona nispet edilen eserlerin bir kısmı da henüz bulunmamıştır. Bu nedenle burada tam bir liste olarak sunma imkânımız olmamakla birlikte, konumuz muvacehesinde önem atfeden eserlerine değineceğiz.

Gençlik yıllarında eğitim için geldiği Paris'te, hocalık yaptığ 1 Paris Üniversite'sinde dil ve gramer ile başlayan derslerinde sonrasinda Aristo'ya dair dersler vermiş ve yine bu konuda eserler kaleme almıştır. Bu dönemde diyalektiğe dair Sumule Dialectices adlı

8 Raymund Gaufredi'nin kimya alanında düşünürü destekleyici bir eser yazdığı, hatta kendisinin Paris Üniversite'sinde Bacon'dan aldığı derslere göre bu eseri kaleme aldığı düşünülmektedir. Bkz, A.G. Little, “Introduction: On Roger Bacon's Life and Works", Roger Bacon Essays, s.27.

9 Bkz, George Sarton, Introduction to the History of Science From Rabbi Ben Ezra to Roger Bacon, vol.II, s.953; A.G. Little, Introduction: On Roger Bacon's Life and Works, "Roger Bacon Essays", s.27. 
özet ile Summa Grammatica adlı gramer özetini yazmıştır. ${ }^{10}$ Yine bu dönemde Aristo Fizik ve Metafiziğine Dair Sorular ve Aristo'ya nispet edilen Bitkiler Üzerine, Nedenler Üzerine adlı eserlere dair Bitkiler ve Nedenler Üzerine Eserleri Üzerine Sorular adlı iki eserinden daha bahsedebiliriz. Bu eserler bir anlamda düşünürün Paris Üniversitesi'nde verdiği derslerinin notları şeklinde kaleme alınmış olmakla beraber, edisyon edilmiş nüshaları henüz bulunmamaktadır. Sorular külliyatı olarak da isimlendirebileceğimiz bu eserlere dair sınıflandırmayı şu şekilde yapabiliriz. (a) Quaestiones süper libros Physicorum Aristotelis. (b) Quaestiones süper librum e Plantis (or Vegetabilibus) (c) Quaestiones in Aristotelis Metaphysica (d) Questiones naturales mathematice astronimice. ${ }^{11} \mathrm{Bu}$ dönemlerde düşünürün ilgisini çeken diğer bir eser de yine Aristo'ya nispet edilen ve içinde Aristo'nun Büyük İskender'e gönderdiği farzedilen mektupları barındıran Secretum Secretorum (Kitabu'1 Esrar/Sırların Sirrı) adlı eserdir. İçinde okkült bilgilerin yanında, astrolojiden, bitkilere kadar pek çok ilginç bilgileri içerdiği söylenmiştir. Kitabın mistik/ezoterik yönünün ağır bastığı zira, söz konusu bilgileri Aristo'nun Yahudiler ve Mısır kanalıyla edindiği, bu bilgilerin de onlara Tanrı tarafından nakledildiği iddia edilmiştir. ${ }^{12}$ Eser tarih boyunca pek çok düşünürün ilgisini çekmiştir. Bacon'ın da buna dair bir eser kaleme aldığı ve bu eserden yararlandığı söylenmektedir. Düşünüre atfedilen eserin girişinde Bacon'ın düşüncelerini içeren bir giriş ve inceleme yazısı vardır. Düşünür bu eseri Paris Üniversitesi'nde hocayken derslerinde sıkça kullanmıştır. Robert Steele'nin Bacon nüshası olarak ifade ettiği eseri 1920 yılında kendi edisyonuyla birlikte yayımlamıştır. ${ }^{13}$

10 Bu eserler ve Aristo'ya dair düşünürün kaleme aldığı eserlerin tam tarihleri belli olmamakla birlikte, Paris'te bulunduğu ilk dönem olan 1237-1247 yılları arasında yazmış olması muhtemeldir. Bkz, Georgette Sinkler, "Roger Bacon" Routledge Encyclopedia of Philosophy, vol.1, s.633; bkz, Roger Bacon, Opera Hactenus Inedita Rogeri Bacon, Fas. 15, Summa Grammatica Magistri Rogeri Bacon; Necnon Sumule Dialectices Magistri Rogeri Bacon, ed. Robert Steele, London-1940

11 A.G. Little, Roger Bacon's Works with References to the Mss. And Printed Editios, "Roger Bacon Essays", s.377

12 Georgette Sinkler, "Roger Bacon" Routledge Encyclopedia of Philosophy, vol.1, s.633; Allan B. Wolter, "Roger Bacon", The Encyclopedia of Philosophy, Macmillian Publishing, vol. 1-2, Londra-1972, s.240

13 Roger Bacon, Opera Hactenus Inedita Rogeri Baconi, Fas.V: Secretum Secretorum Cum Glossis Et Notulis, ed. Robert Steele. Oxford University Press, Oxford-1920; 
Bacon'un en önemli çalışmaları kuşkusuz, Papa IV. Clement'in teşvikiyle kaleme aldığı Opus serisidir. 1266-68 yılları arasında sırasiyla Opus Majus, Opus Minus ve Opus Tertium'u yazmış ve Papa IV. Clement'e göndermiştir. Son iki eser Opus Majus'a ek olarak kaleme alınmış eserlerdir. Majus'ta ortaya çıkn problemleri ve eksiklikleri giderme amacını taşımaktadır. Bu eserlerden Opus Majus'un J.H.Bridges tarafından edisyonlu ve düşünüre dair analitik bir tablonun da eklendiği Latince baskısı bulunmaktadır. Ayrıca eserin İngilizce'ye tercümesi kısmı olarak gerçekleşmiş olmakla birlikte, Opus Terium ve Opus Minus' un sadece Latince baskıları elimizde bulunmaktadır. ${ }^{14}$ Söz konusu bu üç eser, düşünürün en önemli düşüncelerinin olduğu eserlerdir. ${ }^{15}$

Filozofun üzerinde durduğu en önemli meselelerin başında klasik dillerin iyi bir şekilde öğrenilmesine dair kaygıdır. Bunun temelinde hem klasik metinleri doğru anlama, hem de dini metinlerin yorumlanmasında doğabilecek hataları ve yanlış yorumları engelleme amacı vardır. Bu nedenle klasik dillerin öğrenimi hayati bir husus olarak görmüştür. Aynı gerekçe ile Bacon, Latince kökenli Fransızca ve İngilizce dillerinin yanında, antik dünyanın önemli dilleri olan, Grekçe, İbranice, Arapça ve hatta Keldanice'nin öğrenilmesini de oldukça önemsemektedir. ${ }^{16}$ Onun hem Grekçe, hem de İbranice'ye dair bir gramer çalışması vardır. Bu eser The Greek Grammar of Roger Bacon and a Fragment of His Hebrew Grammar ismiyle yayımlanmıştır. ${ }^{17}$ Eseri Bacon'ın Opus Majus'tan sonra kaleme aldığı düşünülmektedir. Yeniçağ biliminin öncülerinden kabul edilen Bacon'un diğer bir önemli eseri ise tabiat felsefesine dairdir. Communia Naturalium Tabiat felsefesinin genel prensiplerini ele aldığı bu eser

Bu kitaba dair tartışmalar için bkz, Stewen J. Williams, "Roger Bacon and His Edition of the Pseudo-Aristotelian Secretum Secretorum", Mediavel Academy of America, vol.69, no:1, 1994, s.57-73.

14 Roger Bacon, Opera Quædam Hactenus Inedia, I.Opus Tertium, II. Opus Minus, III.Compendium Philosophix, Ed. J.S Brewer, London-1859; Roger Bacon, The Opus Majus, Ed\&Int. J.H.Bridges, vol.I,-II-III Williams and Norgate, Oxford1897-1900; Opus Majus'un İngilizce tercümesi Robert Belle Burke tarafından yapılmış ve iki cilt olarak neşredilmiştir. Bkz, Roger Bacon, Opus Majus, trans, R.B.Burke, vol.I-II, Russell\&Russell, New York-1962

15 Bacon'ın bu eserine dair detay onun düşünceleri kısmına ayrıca ele alınacaktır.

16 John Henry Bridges, The Life and Work of Roger Bacon, 64

17 Roger Bacon, The Greek Grammar of Roger Bacon and a Fragment of His Hebrew Grammar, Cambridge University Press, Cambridge-1902 
tam bir ansiklopedi özelliğini taşımakla beraber tamamlanamamış bir eseridir. 1268 yılında yazdığ 1 diğer bir önemli eser ise Communia Mathematica'dır. Matematiğin genel prensiplerini ele aldığı bu eser, onun bir bilim adamı olarak önemli görülen eserlerinden birisidir. $\mathrm{Bu}$, Oxford matematikçileri diye anılan akıma da ilham kaynağı olan eserlerinden biridir. Düşünürün en önemli eserleri içinde yer alan, genelde felsefe muhtasarı şekilde tasarlanmış önemli bir eseri vardır. Bunlardan birincisi olan, Opus külliyatıyla beraber kaleme almaya başladığ1 ve Papa'ya arzetmeyi düşündüğü Compedium Philosophiæ adlı eserini 1268 yılında kaleme almaya başlamış ama tam bir eser olarak ancak, 1271-72 y1lları arasında Compendium Studii Philosophiae ismiyle yayımlanmıştır. Aslında eserin bu hale gelmesi uzun yıllar almıştır. ${ }^{18}$ Bacon'ın hapisten çıktıktan sonra yazdığı son eser ise, bir teoloji muhtasarı şeklinde kaleme alınmış olan Compendium Studii Theologiae'dir. Bu eserin edisyonlu versiyonu 1911 y1linda H.Rashdall tarafından Fr. Rogeri Bacon Compendium Studii Theologiae adıyla yayımlanmıştır. ${ }^{19}$

Bununla birlikte Bacon'a atfedilen irili ufaklı pek çok belgeden bahsetmek de mümkündür. Ayrıca ansiklopedist bir düşünür olarak ele aldığımız Bacon'ı, bilimin muhtelif dallarında kaleme aldığı yazılara da rastlıyoruz. Mesela onun bilimlere dair ilk eserlerinden birisi kimya/simya'ya dairdir ve The Speculum Alchemia adiyla 1541 yılında yayımlanmıştır. Onun hayatında önemli bir yeri olan İbn

18 Düşünürün iki farklı isimle ele almış gibi göründüğü felsefe özeti şeklinde kaleme aldığı eserin orijinal 1271-72'deki baskısında "Studii" kelimesi geçmektedir. Ancak Brewer tarafından gözden geçirilen eser, ilk şeklindeki haliyle isimlendirilmiştir. Bu isimlendirmeden dolayı edit edilen kısmın sadece eserin ilk kısmı olan Compendium Principale olarak adlandırılan zaman zaman da Scriptium Principale olarak anılan eser zannedilmektedir. Ancak Brewer'in edit ettiği nüsha eserin son hali olan Compendium Studii Principale olarak bilinen 1271-2 baskısıdır. Düşürün eserini kullanıp bu esere atıfta bulunan ve Brewer'in nüshasını kullanan araştırmacıların bazılarının eseri Compendium Principale bazıları da Compendium Studii Principale olarak isimlendirmektedirler. Bkz, Roger Bacon, Opera Quædam Hactenus Inedia, I.Opus Tertium, II. Opus Minus, III.Compendium Philosophiæ, Ed. J.S Brewer; Richard Lemay, "Roger Bacon's Attitude Toward the Latin Translations and Translators of the Twelfh and Thirtenth Centuries", Roger BaconEthe Sciences, ed. Jeremiah Hackett, Brill-1997, s.43; ikisinin de aslında aynı eser olduğuna dair bkz, George Molland, "Roger Bacon's Knowledge of Mathematics", Roger BaconEthe Sciences, s.168.

19 Roger Bacon, Compendium Studii Theologiae, ed. H.Rashdall, British Society of Franciscan Studies, Vol.III, London-1911 
Heysem'in (ö.1040) ve hocası Grosseteste'den (ö.1253) etkilenerek yazdığı optiğe dair eseri Pespectiva ayrıca önemli bir eserdir. Bu eserin İngilizce tercümesi ve edisyonu notlarla birlikte daha sonra David C. Lindberg tarafından yapılmıştır. ${ }^{20}$ Ezoterik gizeme ait yazdığı ilginç eserlerden birisi de The Epistola de Secretis ölümünden sonra 1542' de Paris'te basılmıştır. Bununla ilgili George Sarton'un kitabındaki ve A.G.Little'ın makalesindeki ilgili bölümlere bakmak gerekmektedir. $^{21}$

\section{Düşüncesinin Kaynakları}

On üçüncü yüzyılın oldukça etkin ve eklektik düşünce ortamında yetişmiş bir düşünür olan Roger Bacon'ın düşünsel serüveninde iz bırakmış pek çok önemli isim vardır. İslam düşüncesinin zirvesini yaşadığı bu dönemde Avrupa açısından dogmatik düşüncenin en katı olduğu bir ortam vardı. Bu dönem Batı düşüncesi açısından da önemli ve olumlu değişimlerin henüz başladığı bir dönem olarak karşımıza çıkmaktadır. XIII. yüzyıl İslam düşüncesinin İbn Sina, Farabi, (ö.950) Gazzâli (ö.1111) ve İbn Rüşd'ün gibi zirve şahsiyetlerin eserlerinin Latince'ye çevirilerinin yapıldığ 1 ve Avrupa üniversitelerinde okutulmaya başladığı bir dönemdir. Doğu İslam kültürünün, daha sonra kendi kaynaklarına kavuşma iddiası içinde olacak olan Batı'ya destek olup, onu dogmatizm ve skolastisizmin boyunduruğundan kurtarma adına atılan ilk adımlar bu yüzyılda başlamıştır. Bu adımları ilk defa atanlardan biri olan ve gelecekte olacakları bir anlamda öngören Bacon, çağını yansıtan önemli bir filozof olarak karşımıza çıkmaktadır. Bir anlamda Yeniçağ biliminin müjdecisi olarak Bacon'u, ortaçağın ilk bilimcisi ya da ansiklopedist olarak adlandırabiliriz.

Bacon antik dünyanın pek çok filozof ve düşünürüne hayrandır. Özellikle Aristo'ya, Müslüman düşünürlerden İbn Sina ve İbn Rüşd'e özel bir hayranlığının olduğunu söyleyebiliriz. ${ }^{22}$ Bu hayran-

20 Roger Bacon, Roger Bacon and the Origins of "Pespectiva" in the Middle Ages: A Critical Edition and English Translation of Bacon's Pespectiva with Introduction and Notes, trans\&not: David C. Lindberg, Oxford University Press, Oxford-1996.

21 Düşünürün eserlerinin detaylı bir dökümü ve yazmalarına dair geniş bilgi için bkz, A.G. Little, Roger Bacon's Works with References to the Mss. And Printed Editios, "Roger Bacon Essays",375-424; ayrica bkz, George Sarton, Introduction to the History of Science From Rabbi Ben Ezra to Roger Bacon, vol.II, s.963-65

22 Ted Honderich, The Oxford Companion to Philosophy, Oxford University Press, ed. Ted Honderich, 2005-Oxford, s.78 
lık onu Arapça öğrenmenin gerekliliğine dair söylemlere kadar götürmüştür. Bacon'un külliyatına baktığımızda Latin İbn Rüşdçülüğünün izlerini takip etmek mümkündür. Gerek Paris'te, gerekse Oxford'da bulunduğu süre zarfında onun düşünce ve özel hayatında önemi olan düşünürlerin başında hocası R.Grosseteste (11751253) vardır. Hocasının çalışma tarzından bilim anlayışına kadar pek çok açıdan ondan etkilenmiştir. Onun klasikler üzerine çalışması ve bilime yaklaşımı Bacon'un ilim hayatında izleyeceği yolu çizmesinde etkili olmuştur. Hocasının kaleme aldığı Commentary on Aristotle's Posterior Analytics adlı eser onun Aristo'nun eserlerine dair kaleme aldığ Questions (sorular) serisi kitaplara ilham kaynağ olmuştur. Kendisi gibi Paris Üniversitesi'nde ve Oxford'da dersler vermiş diğer bir teolog ve filozof Richard Rufus'un (ö.1260) gayretleri de onu etkilemiştir. Kendisi gibi Fransisken olan Rufus'un Aristo fiziğine ve metafiziğine dair verdiği dersler gerek Fransa'da, gerekse belli bir süre ders vermek için bulunduğu Oxford'da pek çok kişiyi etkilediği gibi Bacon'ı da oldukça etkilemişti. Aristo'nun eserlerine olan ilgisinde hocası R.Grosseteste kadar R.Rufus'unda etkisi azımsanamayacak oranda çoktur. Onun bağlantıda olduğu önemli kişilerin başında kendisi gibi Oxford'da bulunan Adam Marsh, (ö.1259) sonradan Canterbury Archbishop'ı olan Edmund Rich (ö.1240) ve hakkında büyü ve sihirbazlıkla ilgili çokça suçlamaların olduğu Thomas Bungary gibi kişi ve düşünürler vardır. ${ }^{23}$

Bacon'un yaşadığı dönemde çağdaşı olduğu, zaman zaman da eleştirdiği büyük düşünürlerin başında Dominiken ${ }^{24}$ tarikatine mensup, Ortaçağ skolastik Hıristiyan düşüncesinin en önemli şahsiyetlerinden olan, Albertus Magnus (ö.1280) ve Thomas Aquinas (ö.1274) vardır. Bacon'un onları eleştirmenin yanında onlara içten içe bir kıskançlık duyduğu, çağdaşlarına sunulan imkânların bir Fransisken olarak kendine sunulmamasına içerlediği zamanlar olmuştur. Onun kendisinden etkilendiği kişilerin başında çağdaşı ve kendisi de bir Fransisken olan Raymond Lull'u (1232-1315) da zikredebiliriz.

23 Bkz; John Henry Bridges, The Life and Work of Roger Bacon, s.17.

24 Aziz Dominik (Domingo de Guzman) tarafından 1216 yılında kurulmuş Katolik menşeili bir tarikattır. En meşhur müntesipleri arasında Albertus Magnus, Thomas Aquinas ve Meister Eckhart gibi din adamları vardır. Bkz, Stephen F. Brown, Juan Carlos Flores, Historical Dictionary of Medieval Philosophy and Theology, Plymouth-2007, s.205

114 


\section{Ortaçağın İlk Ansiklopedist Düşünürü Roger Bacon}

Hocası Grosseteste'nin yolundan giderek dönemin önemli Aristo yorumcularından olan Bacon, aynı zamanda Platoncu eğilimlere sahip bir düşünür olarak da karşımıza çıkar. Onun Platoncu etkileri, hayranı olduğu St. Augustine'in (ö.430) bir yansımasıyken, Latince tercümeleri üzerinden kendilerini tanıma imkânı bulduğu Müslüman filozoflar İbn Rüşd ve İbn Sina da, Aristo'ya olan hayranlığının vesilesidirler. İlkçağın en önemli sistem filozoflarından Aristo'nun ansiklopedist tavrının kısmi bir yansımasının çağlar sonra Bacon üzerinde yeniden filizlendiğini görmekteyiz. Ortaçağ Avrupa'sının en önemli merkezleri olan Paris ve Oxford'da kendine yer edinmeye çalışan düşünürün bilimsel çalışmaları içinde yaşadığı çağda fazla itibar görmemişse de, kendinden yüzyıllar sonra üzerinde gezdiği topraklarda, modern dünyaya ilham kaynağı olacaktır.

Bacon'un en önemli eserleri arasında sayabileceğimiz Opus Majus ve onların ekleri olan Opus Tertium ve Opus Minus ile Compendium Philosophiæ2 ${ }^{25}$, gerek birçok felsefi ve bilimsel meseleyi bir arada ele alması, gerekse düşünce tarihinin önemli şahsiyetlerinden bahsetmesi bakımından birer ansiklopedi niteliğini taşımaktadır. 1257 yılında çalışmalarına katkı sağlayacağı umuduyla girdiği Fransiskenlerin içinde, siyasi ve sosyal açıdan baskı ve cezalara maruz kalmışsa da, bu dönemin onun çalışmalarına ilham veren kişi ve kitaplarla karşılaşmasına katkıda bulunduğu gerçeğini unutmamak gerekir.

Düşünürün en önemli yanlarından birisi de yeniçağla başlayıp aydınlanma akımıyla devam edecek olan deney ve gözlemin öncelendiği metotların önemine dair yaptığı vurgulardır. O içinde bulunduğu skolastik dünyanın aksine akli kanıt ve deneyin yöntem olarak kullanılmasında ısrarcı olan önemli ortaçağ filozoflarından biridir. Ona göre tek tek ve aralarında herhangi bir uyum olmayan münferit gözlemlerler yeterli değildir. Bunlar metodik bir düzene sokulmalı, nedenleri araştırılarak yasalara bu yolla ulaşmak gerekmektedir. ${ }^{26}$

25 Bu eser zaman zaman felsefenin özeti olması bakımından Summa Philosophiae ismiyle de anılmaktadır.

26 Karl Vorlander, Felsefe Tarihi, çev. Mehmet İzzet, Orhan Saaddettin, sad.Yüksel Kanar, İz Yayıncllık, İstanbul-2004, s.296 
Hayatının kırk yılını sanat ve bilimlere ayırdığını söyleyen Bacon'ın bilime olan düşkünlügü̈, onu zamanındaki düşünürlerden farklı kılan özelliklerin başında gelmektedir. Onun için özelleşmiş bir bilimsel tanım kullanmak mümkün olmamakla beraber, tercüme ve şerhlerini okuduğu, hayranı olduğu Aristo gibi bir ansiklopedist olduğunu söyleyebiliriz. Bunun daha iyi anlaşılması için Compendium Philosophiae' nin içeriğine şöyle bir bakmak yeterlidir.

Compendium Philosophiae adlı eser zaman zaman Scriptum Principale ve Liber Sex Scientiarum olarak da adlandırılmaktadır. Eser dört ana bölümde altı önemli bilim dalını ele almaktadır. Aslında düşünürün Papa IV. Clement'in emriyle yazmaya başladığı eserin ilk şekli onun emirleri uyarınca yazılmıştı. Ancak ona takdim etme imkânı bulamadığı bu eser daha sonra genişletilerek, bahsi geçtiği gibi, 1272 yılında Compendium Studii Philosophiae ismiyle yayımlanmıştır. Eserin ilk hali de, bu eserin bölümlerinden birisidir. Eserdeki altı bilim dalı gramer, mantık, matematik, fizik ya da doğa bilimleri, metafizik ve ahlaktır. Eserin matematik kısmında, skolastik felsefede "quadrivium" olarak adlandırılan, içinde geometri, aritmetik, astronomi ve müziğin de olduğu dörtlü matematik bilimleri mevcuttur. ${ }^{27}$ Eserin üçüncü bölümü olan, fizik ve doğa felsefesi kısmı dört alt başlıktan oluşmaktadır. Filozofun düşünce dünyasının ne kadar geniş olduğunu göstermesi bakımından hayli önemli olan bu bölümde (1) Tabiat felsefesinin genel prensipleri (Communia Naturalium) (2) Göksel bedenler üzerine (3) Unsurlar ve cansız terkipler üzerine (4) Bitkiler ve hayvanlar üzerine adlı başlıklar bulunmaktadır. Bu bölümlemede ikinci, üçüncü ve dördüncü kısımlarda yedi tane tabiat biliminden bahsedilmektedir. Düşünür bu ilimlere dair Opus Majus'ta detaylı şekilde ele aldığı gibi bazı bilimlere dair muhtelif eserleri vardır. Bu bilimler şunlardır: (a) Optik (b) Teorik ve pratik Astronomi (c) Baroloji (ağırlık ve yerçekimi araştırmaları) (d) Zirai kimya (e) İlaç bilimi (f) Deneysel bilimler. ${ }^{28}$ Düşünürün kuşkusuz en önemli eseri olarak kabul edilen Opus Majus' da karşımıza çıkan sınıflandırmalar, onu anlamak açısından önemli bir fırsattır.

$27 \mathrm{Bkz}$, George Sarton, Introduction to the History of Science From Rabbi Ben Ezra to Roger Bacon, vol.II, s.955, John Henry Bridges, The Life and Work of Roger Bacon, s.151, 61, bkz, Roger Bacon, Opera Quædam Hactenus Inedia, I.Opus Tertium, II. Opus Minus, III.Compendium Philosophiæ, Ed. J.S Brewer, s.444

28 A.G. Little, Introduction: On Roger Bacon's Life and Works, "Roger Bacon Essays", s.22 
Opus Majus yedi ana kısma ayrılmaktadır: (a) İnsanın cahilliğinin dört genel sebebi. Bu bölüm içerisinde genelde erdem kavramı, bilginin amacı ve unsurları ele alınırken, otorite, alışkanlık ve önyargıya dair durumların doğruya ulaşmadaki yeri üzerinde durulur. İnsana dair geniş bir değerlendirme sunan bu bölüm birinci cilt boyunca geniş bir yer tutmaktadır. ${ }^{29}$ (b) Felsefe ve Teoloji ilişkisi. Kitabın ikinci kısmını teşkil eden bu kısımda düşünürün bir din felsefecisini andıran görüşleriyle karşılaşmaktayız. Ona göre tüm hakikat aslında kutsal kitapta mevcuttur. Ancak bizi aydınlığa çkarmaya yaracak doğruya ulaşmada felsefe bize yardımcı olacaktır. Tek olan tanrıdan gelen erdem bu dünyaya tek bir amaç için verilmiştir. Bacon felsefenin ilahi bir kaynaktan geldiğine inanmaktadır. Bu kaynak tarihte Mısırlılar ve Yahudiler aracılı̆̆ıyla Hıristiyanlara kadar gelmiştir. Eski toplumlarda da ahlak, bilgi, sanat mantık ve gramer gibi kavramlar vardır. Ona göre bu bilgi ve hikmet birikimi Hıristiyanlıkta birleşmektedir, Düşünür burada Hıristiyanlığı düşüncenin merkezine oturtmaya çalışmaktadır. ${ }^{30}$ (c) Dil çalışmaları kitabın üçüncü kısmını oluşturmaktadır. Bacon'ın düşünce hayatında önemli bir yeri olan bu kısımda her biri başlı başına kitap olacak bölümleri içermektedir. Grekçe ve İbranice'ye dair müstakil bir gramer çalışması da olan düşünürün klasik merakına dair bilgileri eserin bu kısmında görmekteyiz. (d) Matematiksel Bilimler: Eserin dördüncü kısmı olan bu bölümde, Compendium Philosophiae'de karşılaştı̆̆ımız, quadrivium içinde geçen ilimler detaylı bir şekilde incelenmektedir. Eserin birinci cildinin en geniş kısımlarından biri matematik ilimlerine ayrılmıştır. ${ }^{31}$ (e) Optik ve perspektif: Düşünürün uğruna oldukça fazla para harcadığı, hocası Grosseteste'nin izinden gittiği alandır. (f) Deneysel bilimler (g) Ahlak. ${ }^{32}$

Yukarıda kısaca özetlediğimiz bu sınıflandırmalardan sonra, şimdi de düşünürün optikten, eğitime; takvime dair çalışmalarından astronomiye; kimya, matematik ve deneysel bilimlere; ahlaktan coğrafyaya kadar uzanan geniş bir alanda söz söylediği bilimler

29 Bkz, Roger Bacon, The Opus Majus, Ed\&Int. J.H.Bridges, vol.I, Williams and Norgate, Oxford-1900, s.XCIII-XCVI, 1-32.

30 Bkz, Roger Bacon, The Opus Majus, Ed\&Int. J.H.Bridges, vol.I, s.XCVI-C, s.33-65.

31 Bkz, Roger Bacon, The Opus Majus, Ed\&Int. J.H.Bridges, vol.I, s.97-403.

$32 \mathrm{Bkz}$; George Sarton, Introduction to the History of Science From Rabbi Ben Ezra to Roger Bacon, vol.II,, s.955; John Henry Bridges, The Life and Work of Roger Bacon, s.151; Roger Bacon, Opus Majus, trans. R.B.Burke, vol.II, s.419-492 
hakkındaki görüşlerinden bir kısmını, onun ansiklopedist kişiliğini ortaya koymak bakımından kisaca ele alalım.

\section{Optik}

Düşünürün bilimsel araştırmalarının en önemlilerinden birisi kuşkusuz optik üzerinedir. Opus Majus'un beşinci kısmı büyük bir oranda optik ilmine ayrılmıştır. ${ }^{33}$ Düşünürü optik ilmi hususunda etkileyen düşünürlerin başında ilk çağın önemli düşünürü Batlamyus'un (ö.165) yanında, ünlü Müslüman bilimci İbn Heysem'de gelmektedir. Düşünürün Opus Majus'ta ortaya koymaya çalıştı̆̆ı, gözün fizyolojisi, göz ve beyin anatomisi, ışığın göze geliş pozisyonu, ışığın göz içindeki lenslere yansıma şekilleri gibi pek çok başlık altında izah edilmeye çalıştığı optikte, İbn Heysem'in Latince'ye çevrilen eserinin önemli bir etkisi vardır. Düşünürün optik başlığı altında ele aldığı konuların içinde, hayal gücü, sağduyu ve hafıza, optik sinirler ve gözün yapısı, algı, 1şık, uzaklık gibi pek çok husus mevcuttur. Kendisinden yaklaşık bir yüzyıl önce İbn Heysem'in Kitabu'l Menâzır adlı ünlü optik kitabı Cremona'lı Gerard (ö.1187) tarafından Opticae Thesaurus Alhazeni adıyla Latince'ye çevrilmişti. Bu kitabın deneysel/tecrübi bilimlere dair çalışma yapan Avrupalı düşünürler arasında etkisi büyük olmuştu. İbn Heysem ikinci Batlamyus olarak nitelendirilmişti. Düşünürün İbn Heysem/Alhazen'e olan ilgisinin başında hocası Grosseteste'nin çalışmaları da vardır. O ayrıca bu alanda diğer Müslüman düşünür ilk İslam filozof olarak nitelendirilen Kindi'den (ö.866) de etkilenmiştir. ${ }^{34}$

Klasik çağın önemli düşünürleri Batlamyus ve Öklid'in (ö. M.Ö. 275) yanında, Bacon İbn Heysem ve Kindi gibi Müslüman düşünürlerden de yararlanmış, kendisinden sonra bu alanda araştırma yapan John Peckham, (ö.1292) William of Saint Cloud'u ve Leonard Digges (ö.1559) gibi Avrupalı araştırmacıları etkilemiştir.

33 Roger Bacon, Opus Majus, v.II, trans. R.B.Burke, s.419-582

34 Roger Bacon, Opus Majus, v.II, trans. R.B.Burke, s.420, 424. 430,431,433, 434, 436.., A. Mark Smith, Ptolemy's Theory of Visial Perception: an English Translation of The Optics with Introduction and Commentary, The American Philosophical Society, vol.86, part.2 Philedelphia-1996, s. 58-60; John Henry Bridges, The Life and Work of Roger Bacon, s.38, 104; George Sarton, Introduction to the History of Science From Rabbi Ben Ezra to Roger Bacon, vol.II, s.957 


\section{Takvim}

Düşünürün en önemli çalışmalardan birisi de takvim konusundadır. O kendisinden sonra gerçekleşecek takvim reformunun bir anlamda öncüsü olmuştur. Takvim ve astronomiye dair olan ilgisinin kaynağı ise hocası Grosseteste'dir. Yaşadığı zamanda yıllık takvimin 365 gün olarak hesaplanmasının yanlış olduğunu ifade ederek durumu Opus Majus'ta ele almış ${ }^{35}$ ve hamisi olan Papa IV. Clement'e de durumu izah etmeye çalışmıştır. Zira her sene eksik olan 6 saat, zamanla dini günlerin hesaplanmasında yanlışlıklar meydana getirmektedir. ${ }^{36}$ Papa IV. Clement'in çok erken vefat etmesi onun bu çalışmalarını akamete uğratmışsa da Gregorian takvimin isim babası olan Papa XIII. Gregor'ün girişimleriyle meşhur Gregorian takviminin ortaya çıkmasında düşünürün görüşlerinden faydalanılmıştır. ${ }^{37}$

\section{Ĕgitim}

Bacon'un hayatında gerçekleştirmeye çalıştığı en önemli amaçların başında eğitime dair yenilikler gelmektedir. Skolastik bir eğitim hayatından gelen düşünür, Opus Majus'u bizatihi eğitime dair kafasındaki düşüncelerin bir neticesi olarak ortaya koymuştur. O zamanındaki yozlaşmayı görüyor ve bunun sebebinin de kendisinin de mensubu olduğu skolastik eğitim sistemi olarak kabul ediyordu. Ona göre, hocası Grosseteste zamanında bile insanlar kendi zamanlarından daha iyi durumdaydılar. Bu kişiler daha iyi matematik bilmekte ve dine dair bilgileri, yorumlardan çok doğrudan kutsal metinden almaktaydılar. Kendisinin de ders verdiği Paris Üniversitesinde klasik trivium ve quadrivium ${ }^{38}$ olarak adlandırılan ilimlere daha çok önem veriliyordu. Ona göre bu eğitim sistemi oldukça hantal ve ağırdı. Düşünür birincil olarak öğrenciye tartışma prensiplerini bilmeyi ve kendisine uygun unsurları kullanabilecek bir insan olmayı öğretmek gerektiğini düşünüyordu. Gramer, metinleri anlamak için önemli bir unsurdur. Ancak Latince'den doğmuş dilleri tam olarak anlayabilmek için sadece o dillerin gramerini değil,

\footnotetext{
${ }^{35}$ Roger Bacon, The Opus Majus, Ed\&Int. J.H.Bridges, vol.I, s.269-271

${ }^{36}$ Roger Bacon, The Opus Majus, Ed\&Int. J.H.Bridges, vol.I, 272

${ }^{37} \mathrm{Bkz}$, George Sarton, Introduction to the History of Science From Rabbi Ben Ezra to Roger Bacon, vol.II,, s.957; David Ewing Duncan, The Calendar, , Avon Books, London-1998, s.1

38 Gramer, retorik ve mantık ilimleri Trivium içerisinde yer alırken, aritmetik, geometri, astronomi ve müzik quadrivium içerisinde yer almaktadır.
} 
diğer dilleri de bilmeliyiz. ${ }^{39}$ Düşünürün IV. Clement'e sunduğu Opus Majus'un daha başında, eğitimin karşıtı olarak gördüğü cehaletten kurtulmak için dört tane önemli problemin aşılması gereğini ortaya koymaktadır. Cahilliğin nedeni olarak düşünür şu hususları saymaktadır: (a) değersiz otoriteye itaat etmek (b) alışkanlıkların otoritesine tâbi olmak (c) popüler önyargilarımız (d) kendi erdemlerimize dair sahip olduğumuz gururumuz. Tüm bunlar insanın cehaletinin nedenlerindendir ve insan ancak eğitim yoluyla bu problemlerin üstesinden gelebilir. ${ }^{40}$

\section{Dil çalışmaları}

Bacon'ın eğitime dair düşüncelerinde önemli bir yeri olan husus da, klasik dillere dair görüşleridir. Düşünürümüz bir bilim adamı, filozof ve dini bir grubun mensubu olarak, okuduğumuz metinlerin doğru bir şekilde anlaşılması ve yorumlanması için, dile verdiği öneme dair zamanını aşan görüşler ortaya koymuştur. $\mathrm{O}$, dile dair müstakil çalışmalarının yanında, belli başlı önemli eserlerinde de bu konuya olan hassasiyetini ortaya koymuştur. Grek ve İbranice dillerine dair müstakil eserleri olan düşünürün, dilin kullanımına dair diyalektik ve gramer özetlerini içeren eserleri ayrıca önemlidir. ${ }^{41}$ En önemli eseri olan Opus Majus'un üçüncü kısmı dil çalışmalarına ayrılmıştır. ${ }^{42}$ Compendium Philosophia'nın ilk kısımları da gramer ve mantık konularını işlemektedir. ${ }^{43}$ Düşünürün bu denli önem verdiği dil çalışmalarını öncelemesinin önemli nedenleri vardır. Opus Majus'da dile getirdiği eğitim reformunun içinde dil çalışmaları da vardır. Skolastik düşünce içinde trivium/üçleme içinde hali hazırda okutulan gramer ve mantık ona göre yeterli değildir. Bu eksiklik özellikle de gramer alanında kendisini göstermektedir. Henüz genç bir bilim adamıken Aristo'nun eserlerinin okutulduğunu duyduğu Paris Üniversitesi'ne gitmesindeki temel amacı klasik dillere ve antikiteye olan düşkünlügüdür. Onun temel iddiası felsefeye dair metinleri iyice anlayabilmek için, o metnin orijinal dilini bilmemiz

39 Bkz, Stewart C. Easton, Roger Bacon and His Search for A Universal Science, s.1213,16

40 Roger Bacon, The Opus Majus, Ed\&Int. J.H.Bridges, vol.I, s.2-4.

41 Eserleri bölümüne bakınız.

42 Bkz, Roger Bacon, The Opus Majus, Ed\&Int. J.H.Bridges, vol.I,-s.66-96

43 Compendium Philosophiae' de gramer ve mantık başta olmak üzere klasik dillerini öğrenilmesi gereğine dair pek çok ifade bulmak mümkündür. Bunlardan bazıları için bkz, Roger Bacon, Opera Quædam Hactenus Inedia, I.Opus Tertium, II. Opus Minus, III.Compendium Philosophiæ, Ed. J.S Brewer, s.396,436, 438, 443, 462 
gerektiğidir. Böyle bir bilgi o kişinin Latince bilgisine de önemli katkılar sağlayacaktır. Ona göre kullandığımız çoğu felsefi ve bilimsel eserlerin ana kaynakları, İbranice, Grekçe ve Arapça' dır. Bu nedenle bizlerin de bu klasik dilleri bilmemiz gerekmektedir. Düşünüre göre çoğu Latince kelime, Grekçe bilinmeden tam olarak anlaşılamaz. Sağlıklı bir dil bilgisi hayati derecede önemlidir. Zira özellikle dini ve bilimsel metinlerin anlaşılması ve doğru yorumlanması buna bağlıdır. Düşünürü bu yargıya götüren şey, aslında dil çalışmalarına yüklediği hayati önemdir. O dilleri bilgiye ulaşmak için bir araç olarak görüyordu. Bu aracın en önemli aşamaları ise, bilgiyi onun zamanına kadar taşıyıp koruyan klasik dillerin öğrenilmesi ve metinlerin orijinalleriyle yüzleşilmesi gereğidir. ${ }^{44}$

Bacon Latin Batı dünyasında Aristo'nun mantığı dışında diğer konular üzerinde çalışma yapan ilk düşünürlerden birisidir. Kendisinden ilham aldığı hocası Grosseteste'nin yolundan giderek, Paris'te okutulduğunu duyduğu Aristo'nun fizik ve psikoloji derslerine katılmak için Oxford'dan ayrılmış ve Alexander of Hales (ö.1245) ve William of Auvergne'nin (ö.1249) Aristo okumalarını takip etmiştir. Sonrasında pek çok mütercim ve düşünürün klasik eserleriyle yüzleşmiştir. Bacon'ı önceleyen yüzyılı, Latin Batı dünyasında düşünsel anlamda yeni bir dönüşümün başladığı bir dönem olarak görebiliriz. Skolastik yaklaşımın son derece nüfuzlu olduğu bu zaman diliminde, klasik dillerden yapılan tercümeler ve özellikle de Arapça'dan yapılan klasik tercümeler, gelecekteki değişimlerin habercisi durumundadır. Toledo Arcbishop'ı Raymond Lulle'ün büyük çabaları ve kurduğu tercüme evi sayesinde, İslam dünyasından ve özellikle de Endülüs'ten getirilen pek çok eser tercüme edilmişti. Burada tercüme edilen eserlerden özellikle Aristo fiziği başta olmak üzere ilk önce, Alexander Neckam (ö.1217) gibi düşünürlerce XII. yüzyılın sonlarında Paris'te, XIII. yüzyılın başlarında da Oxford ve çevresinde okutulmaya başlanmıştı. Bu tercüme hareketi Latin İbn Rüşdçülüğü olarak bildiğimiz akıma dönüşerek, başta Paris olmak üzere, zamanın en önemli üniversiteleri olan

44 Bkz, J.S.Bewer, "Preface" Opera Quædam Hactenus Inedia, I.Opus Tertium, II. Opus Minus, III.Compendium Philosophix, (içinde) Ed. J.S Brewer, s.XXXV; A.G. Little, Introduction: On Roger Bacon's Life and Works, "Roger Bacon Essays", s.23, 24, 62; Georgette Sinkler, "Roger Bacon" Routledge Encyclopedia of Philosophy, vol.1, s.635 
Oxford, Cambridge, Padua ve Toledo gibi merkezlerde büyük etkiler meydana getirmişti. ${ }^{45}$

Bacon'ın dile dair çalışmalarında onu motive eden unsurların başında klasik dillerden yapılan doğru tercümeler vardır. Kendisinin özellikle işaret ettiği, Gerard Cremona, Micheal Scot, (ö.1232) Alured of England, Hermann the German (ö.1272) ve William of Moerbeke (ö.1286) önemli mütercimlerdir. Özellikle Gerard, Scot ve Hermann, Arapça'dan pek çok önemli eser tercüme etmişlerdir. Uzun yıllar Endülüs'te bulunup Arapça öğrenen Gerard Cremona, Batlamyus'un Magesti'sini, Aristo'nun Meteloroji'sini, Kindi'den bazı risaleleri ve en önemlisi İbn Heysem'in Kitabu'l Menâzir'ini (optik) çevirmiştir. Şahsen tanıştığı Alman Hermann'ın Aristo'nun Retorik, Poetik ve Etik tercümeleri düşünürün ilgisini çeken eserlerdir. XIII. yüzyılın ilk yarısında imparator II. Frederick'in desteğiyle Endülüs'te bulunan Scot, Aristo'nun eserlerini İbn Rüşd şerhleriyle beraber tercüme etmiştir. Bu mütercimler içinde Bacon'ın özellikle Flamenk William Moerbeke'nin doğrudan Grekçe'den yaptığı tercümeler hakkında yaptığı eleştiriler dikkate değerdir. Thomas Aquinas'ın kullandığı bazı nüshaların özel ricayla Moerbeke'ye yaptırdığ 1 düşünülmektedir. Ancak Moerbeke'nin bilim konusunda yeterli bilgisi olmadığından yaptığı tercümelerin hatalarla dolu olduğu ve bunu kullananların da aynı hataları devam ettirdiğine dair kanaatler vardır. Bu kanaatlerin bir gereği olarak Bacon, yanlış yapılan Aristo tercümeleri hakkında "hiç yapılmasa daha iyi olurdu" diyerek düşüncesini ifade etmiştir. Hatalı tercümelerle çalışmanın vakit kaybı olduğunu söyleyen Bacon, gerçek faydanın ortaya çıkmasının ancak orijinal metinleri çalışmakla mümkün olacağını söylemiştir. ${ }^{46} \mathrm{Bu}$ nedenledir ki antik dillerin bilinmesine dair ısrarını daima korumuştur. Bacon'a göre Latince kaynaklı Fransızca ve Íngilizce'nin yanında araştırmacıların, özellikle İbranice, Grekçe, Arapça ve Keldanice gibi dilleri bilmeleri gerekmektedir. Kadim dönemin hikmetlerini ve erdemlerini doğru bir şekilde öğrenmek için o dili orijinalinden okumak gerekmektedir. ${ }^{47} \mathrm{Bu}$ dilleri, anadilimiz gibi olmasa da yanlışı doğrudan ayıracak düzeyde bilmemiz gerek-

45 Bkz, John Henry Bridges, The Life and Work of Roger Bacon, s.19-20

46 Bkz, John Henry Bridges, The Life and Work of Roger Bacon, s.64-72

47 J.S.Bewer, "Preface" Opera Quædam Hactenus Inedia, I.Opus Tertium, II. Opus Minus, III.Compendium Philosophiæ, (içinde) Ed. J.S Brewer, s. LVIII 
mektedir. Araştırmacıların metinleri sadece Latince tercümelerinden okumaları hataların devamını sağlamaktan başka bir şeye yaramamaktadır. Bu hatalar ise özellikle Íncil ve Aristo metinlerinin doğru anlaşılmasını zorlaştırmaktadır. Ona göre sahip olduğumuz pek çok İncil ve Aristo tercümeleri vahim hataları barındırmaktadır. Özellikle Aristo tercümelerindeki hatalara işaret etmek için, “eğer elimde yeterli gücüm olsaydı, bu hatalı tercümelerin hepsini yakardım" diyecek kadar ileri gitmiş bir düşünürdür. ${ }^{48}$

Klasik dillere bu denli düşkün olan Bacon'ın Grekçe ve İbranice bilgisi hususunda şüphe yoktur. Hatta kendisinin, okuryazar bir kimseye Grekçe okumasını üç gün içinde öğretebileceğini iddia edecek kadar ileri giden düşünürün ${ }^{49}$ Arapça bilgisi hususunda bazı çelişkiler vardır. Onun gerek Oxford ve gerekse Paris'teki öğrencilik yıllarında Arapça öğrendiğine dair haberlerin yanında, Arapça bilmediği ama Müslüman bilginlere büyük ilgi duyduğu şeklinde açıklamalarda bulunanlar olmuştur. Bunu ifade edenlerin başında Stewart C. Easton gibi araştırmacılar vardır. Bu araştırmacıların Bacon’ın Arapça bilgisine dair bu kanaatlerinin kaynağı ise düşünürün Paris Üniversitesinde verdiği dersler sırasında bazı kelimeleri bilmediği ya da yanlış okuduğu, bu durumun İspanyol öğrenciler tarafından fark edilerek alaya alındığına dair söylentidir. ${ }^{50} \mathrm{Bu}$ söylentiye neden olan metindeki kelimelerin Arapça değil de, İspanyolca olduğuna dair fikirler beyan edip, onun Arapça bilgisinin olduğunu ifade edenler de olmuştur. Bizim kanaatimizde düşünürün İbranice kadar olmasa da, onun önemini kavrayacak ve metinlere nüfuz edecek düzeyde Arapça bildiği yönündedir.

Bacon'un her bir araştırmacı ve öğrenci için Latince kökenli Fransızca ve İngilizce'nin yanında İbranice, Grekçe, Arapça ve Keldanice öğrenilmesi gereğine dair ısrarının önemli nedenleri vardır. Bunlardan bir kısmı yukarıda da ifade ettiğimiz dini, felsefi ve bi-

48 John Henry Bridges, The Life and Work of Roger Bacon, s.72-73, A.G. Little, Introduction: On Roger Bacon's Life and Works, "Roger Bacon Essays", s.14

49 A.G. Little, Introduction: On Roger Bacon's Life and Works, "Roger Bacon Essays", s.15

50 Stewart C. Easton, Roger Bacon and His Search for A Universal Science, s.26; George Sarton, Introduction to the History of Science From Rabbi Ben Ezra to Roger Bacon, vol.II, s.961 
limsel metinlerin iyi anlaşılmasına yönelik kaygılardan kaynaklanmaktadır. ${ }^{51}$ Bunun yanında bu dilleri öğrenmek diplomatik, ticari kaygıların yanı sıra dinin yayılması için yürütülecek misyonerlik faaliyetleri açısından önemlidir. ${ }^{52}$ Onun özellikle İbraniceye ve Yahudilere empati ile yaklaştı̆̆ını söyleyebiliriz. Ona göre Tanrı tarafından insanlığa verilmiş olan bilgi, Yahudiler kanalıyla Greklere ulaşmıştır. Hatta bazı Yahudi kaynakları Aristo'nun sahip olduğu bilgiyi Yahudi kaynaklarından aldığını ya da onun bizzat bir Yahudi olduğuna dair görüşler ortaya koymuşlardır. ${ }^{53}$

\section{Matematik ve bilimlere dair}

Bacon’ın en önemli özelliklerinden olan bilim adamı yönünü destekleyen şey matematiğe duyduğu saygı ve ona izafe ettiği önemdir. Onu tam bir matematik bilgini olarak nitelendirmek mümkün olmamakla birlikte, onun bu sahada yazdıkları bu bilimin ne kadar hayati bir öneme sahip olduğunu ortaya koyması bakımından dikkate değerdir. Bacon matematiğin özellikle pratik yararında ısrarcı olurken, onu sadece bilimsel alanla sınırlandırmamış, teoloji alanında da uygulamaya çalışmıştır. Opus Majus'un dördüncü kısmını teşkil eden matematik, ona göre vahyin dişında bilgi için en önemli kaynak durumundadır. Bilginin bütün meyvelerinin toplanması da ancak matematik sayesinde mümkün olacaktır. Ona göre matematik, bilimler için kaynak durumundadır. ${ }^{54}$ Bu kaynak tabiat bilimlerini keşfetmemize, ona ulaşacak kapıyı açmamıza yarayacak bir anahtar konumundadır. O ayrıca felsefenin alfabesi, doğa bilimleri için bir ihtiyaç ve zorunlu bir araç konumundadır. ${ }^{55}$

Bacon'a göre tüm ilmi faaliyetlerimizde matematik bize doğru düşünme ve aynı sonuca ulaşmada uygulayacağımız akıl yürütmeyi ortaya koymamıza yardımcı olmaktadır. Bundan dolayı, yukarıda da beyan ettiğimiz gibi, matematik tüm bilimler için kaynak

51 J.S.Bewer, "Preface" Opera Quædam Hactenus Inedia, I.Opus Tertium, II. Opus Minus, III.Compendium Philosophiæ, (içinde) Ed. J.S Brewer, s.LIII

52 George Sarton, Introduction to the History of Science From Rabbi Ben Ezra to Roger Bacon, vol.II, s.961

53 George Sarton, Introduction to the History of Science From Rabbi Ben Ezra to Roger Bacon, vol.II, s.962

54 Georgette Sinkler, "Roger Bacon" Routledge Encyclopedia of Philosophy, vol.1, s.634; George Sarton, Introduction to the History of Science From Rabbi Ben Ezra to Roger Bacon, vol.II, s.956

55 Roger Bacon, The Opus Majus, Ed\&Int. J.H.Bridges, vol.I, s.97-98; G. Little, “Introduction: On Roger Bacon's Life and Works", Roger Bacon Essays, s.15 
durumundadır. Bunu Bacon Opus Majus'un matematik kısmının üçüncü bölümünde şu gerekçelere dayandırmaktadır: (a) Diğer tüm bilimlerde matematik örneklemeler kullanmaktayız. Bu bize herhangi bir karışıklığa uğramadan asıl çözüm noktasını göstermeye yardım etmektedir. (b) Matematiksel bilgi bize doğuştan gelen bir bilgidir ve ihtiyaç anında ortaya çıkmaktadır. (c) Matematiksel doğrular diğerlerinden daha önce keşfedilir. (d) Diğerlerinden (doğrulardan) daha kolay anlaşılırlar. (e) Öğrenciler onu kapasiteleri oranında elde edebilirler. (f) Bu durum küçük çocuklarda müziğe dayanan aritmetiksel oranlarda ortaya çıkmaktadır. (g) Şeylere dair bilgimiz, bilinenden hareketle bilinmeyeni elde etmek yoluyla oluşur. Ancak matematiksel bilgi mutlak ve göreceli olmak üzere iki karaktere sahiptir. (h) Matematiğin kanıtlamaları daha tamdır. Fizikten, metafizikten ve etikten farklı olarak zorunlu bir ikna gücüne sahiptir. (i) Diğer bilimlerdeki belirsizlik ancak matematikle doğrulanarak giderilebilir. (j) Matematiğin nesneleri doğrudan hislerimizle algilanabilirler.

Düşünürün matematiğe olan ilgisi onun eğitim alg1sı ve klasik düşünceye olan düşkünlüğüyle de yakından ilgilidir. Eğitim reformu konusundaki düşüncelerinde, müşteki olduğu hususların başında kendini önceleyen otuz ya da kırk yıllık dönemde matematik ilminin ihmal edilmiş olmasıdır. Onun bu ihmalden kastettiği matematik ilimler içinde, gramer, mantık ve müzik de bulunmaktadır.56 Düşünürün Opus Majus'taki matematiksel bölümlemesi Farabi'nin dokuzlu tasnifine benzemektedir. ${ }^{57}$ Ayrıca o diğer bilimlerde olduğu gibi gerek Müslüman, gerekse Grek dünyasının önemli şahsiyetlerinin matematik görüşlerinden etkilenmiştir. Bunların başında, Aristo'nun Elementler'inin ve Öklid'in Optik'inin bilgisine sahipti. Ayrıca matematik alanında Theodosiufs, Hipparchus, Appollonius ve Archimedes gibi ilkçağ filozoflarından haberdardı. Bunun yanında optikte kendisinden çok yararlandığ İbn Heysem, İbn Sina, İbn Rüşd, Kindi ve sayılar, geometri ve matematiğe dair pek çok eseri Arapça'ya çeviren Sabit bin Kurra onu

56 Lynn Thorndike, "The True Roger Bacon II", The Amerikan Historical Reviev, vol. 21, issue 3, 1916, s.469

57 Bacon'ın muhtemelen Farabi'nin sayılarla ilgili D.Gundisalvi tarafından on ikinci yüzyılda tercüme edilen Liber de scientiis earumque numero partibus et praestantia adlı eserinden haberdardı ve ondan hayli etkilenmişti. Bkz, Roger Bacon, The Opus Majus, Ed\&Int. J.H.Bridges, vol. I, s.100-103 
etkilemişti. ${ }^{58}$ Onun Latin Batı dünyasında Aristo'nun mantığı haricinde diğer konuları da çalışıp, ders veren ilk düşünürlerden olduğunu biliyoruz. Matematiğe dair müstakil bir ders vermemesine rağmen, bu bilime olan ilgisi kendisinden yüzyıllar sonra gelişecek olan 'Oxford Matematikçileri'ne ilham kaynağ 1 olacaktır. ${ }^{59}$

\section{Astronomi-Astroloji}

Bacon'un matematik anlayışının pratik yönünü teşkil eden astroloji ya da astronomiye dair görüşleri, düşünürün renkli, popüler bilimsel görüşleri arasında sayılabilir. Kendisinin uzun yıllar hapis yatmasına neden olan suçlamalardan bazılarının kaynağında astrolojiye duyduğu ilginin bir yansıması olarak kısmen doğru kısmense efsanevi bilgilere dayanan astrolojik ve astronomik bilgiler vardir.

Tarih boyunca aslında tüm bilim adamları bir şekilde astrolojiyle ve onun daha bilimsel hali olarak sonradan sistemleşen astronomiyle ilgili olmuşlardır. İnsanın bilemediği şeyler ya da gizemler hakkında ezoterik anlamlar ya da cevaplar bulma arayışında astrolojik unsurlar tarih boyunca kullanıldığı gibi, bunların halen de belli oranda değerinin olduğunu söyleyebiliriz. Diğer bilimleri anlayabilmek için matematiğin olmazsa olmaz bir şart olduğunu söyleyen Bacon, içinde astroloji ve astronominin de olduğu bir bilimler topluluğunu kastetmekteydi. Astronomi bazen Opus Majus'un matematik kısminda müstakil bir alt başlık olarak, bazen de salt matematik konuları içinde de yer almaktadır.

Bacon'ın astronomiye olan ilgisinin diğer bilim dallarıla olan uğraşının bir sonucu olduğu söylenebilir. $\mathrm{O}$ da hocası Grosseteste'nin yolundan giderek hem Batlamyus'un hem de ünlü Müslüman düşünür Bitruci'nin (ö.1217) astronomiyle ilgili görüşlerine ilgi duymuştur. Klasik coğrafya ve astronominin en önemli kaynağ olan Batlamyus'un verilerinden yola çıan Müslümanlar, astronomiyle ilgili daha gelişmiş bilgilere sahip olmuşlardı. Batlamyus astronomisiyle izah edemediğimiz, doğa felsefesiyle çelişen unsurlar Bitruci'nin bakış açısıyla önemli bir aşama kaydetmişti. Zira Bitrûcî'nin Bacon'ı etkileyen en önemli noktası hayranı olduğu

58 David Eugene Smith, The Place of Roger Bacon in The History of Mathematics, "Roger Bacon Essays", s.160

59 Bkz, Roger Bacon, The Opus Majus, Ed\&Int. J.H.Bridges, vol. I, s.103-108 
Aristo'nun fiziğine uymayan Batlamyuscu eksantirik ve episikıl düzenekleri eleştirerek fiziği öncelemesidir. Bunun bir sonraki aşamasında âlemin, evrenin merkezi olma konumundan çıkmasıyla sonuçlanacaktır. ${ }^{60}$ Bacon'ı etkileyen astronomi görüşlerinin oluşmasinda Bernard of Verdun ve William of Saint Cloud gibi Fransız Fransiskenlerin de etkisi vardır. ${ }^{61}$

Bacon'ın astronomiyle ilgili fikirleri, matematikten fiziğe doğru giden bir çizgiden bakıldığında dikkate değer bir öneme sahiptir. Astronomiden sağlanan verilerin zaman zaman astrolojik amaçlar için kullanılması burada dikkate değer noktalardan bir tanesidir. Astrolojiyle sihir arasında kesin bir ayrım yapan düşünür, kendisinin de suçlanmasına neden olacak olan astrolojik verilere inanıyordu. Onun için aslında astroloji ikiye ayrılmaktaydı: meşru olan ve batıl inançlara dayanan, yasaklanmış olan. Kendisinin meşru olana inandığını farz etmekle beraber hangi verinin batıl ve yasaklanmış olduğuyla hangisinin sahih ve meşru olduğunu ortaya koyma imkân ve kriterinin net olmadığını da söylemek gerekir. ${ }^{62}$ Ancak düşünürün bu meşruiyeti kendi mensubu olduğu din ve kültürü yüceltmek için kullanarak sağlamaya çalıştığını söyleyebiliriz. $\mathrm{O}$ her ne kadar, yıldızlara olan inancın, yani onların insan hayatı üzerindeki etkisine dair kabulün asırlardır var olan yanlış bir kanaat olduğunu söylese de, Hıristiyanlığı ve Hıristiyanları yüceltmek için bazı astrolojik verileri kullanmaktan çekinmemiştir. Ona göre tarih boyunca astrolojiyi şarlatanlık olarak kullananlar olduğu gibi, bilgilerine itibar etmemiz gereken Batlamyus, İbn Sina ve Messahala (Maşaallah ibn Athari/ö.815) gibi önemli astrologları da vardır. ${ }^{63}$ Her ne kadar astronomik epistemolojiyi astrolojik tahminler için kullanmanın ve bunu ontik bir düzlem haline getirmenin sakıncalarını ifade etmiş olsa da, yukarıda da ifade edildiği üzere Hıristiyanlığa ve astronomiye dair dikkate değer analojiler yapmaktan

\footnotetext{
60 Latince kaynaklarda Alpetragius olarak geçen Ebu Ishak b. El-Bitrûcî Bacon'1 bir yüzyıl kadar önceleyen bir düşünürdür. Aristo fiziğine dair yorumları Bacon ve sonrasındaki astronomi çalışan pek çok Avrupalı düşünürü etkilemiştir. Ünlü astronomi eseri Kitabu'l Heyet 1217 yılında Latince'ye çevrilmiştir.

61 George Sarton, Introduction to the History of Science From Rabbi Ben Ezra to Roger Bacon, vol.II, s.956

62 George Sarton, Introduction to the History of Science From Rabbi Ben Ezra to Roger Bacon, vol.II,, s.956

63 Lynn Thorndike, "The True Roger Bacon II", The Amerikan Historical Reviev, vol. 21, Issue 3, s.471
} 
çekinmemiştir. Ona göre bu âlem diğer gezegenlere göre çok küçük olmasına rağmen çok önemli bir konuma sahiptir. Dünyamızdaki coğrafi yapıları anlamak için eğer astronominin verilerini kullanırsak, kutsal kitapta adı geçen yerlerin fiziksel özelliklerini ve konumlarını tespit edebiliriz. Astronominin enstrümanları ile güçlenen bir coğrafya anlayışı bizim için daha kullanışlı olacaktır. ${ }^{64} \mathrm{Bu}$ arada düşünürün zaman zaman işaret ettiği önemli bir husus vardır. Astronominin verileri teolojik bilgilerin doğrulanması için kullanılabilmektedir. Ancak astronomik verilerin doğru bir şekilde analiz edilebilmesi için matematiğin ve özellikle de aritmetiğin zorunlu olduğu unutulmamalıdır. ${ }^{65}$ Astronomik veriler, gezegenlerin durumu etrafımızda olup biteni anlamak, doğayı daha iyi tanımlamak için önemli verileri barındırmaktadır. Gezegenlerin konumları ve durumları bizleri etkilemektedir. Dünyamızdaki iklimsel değişimleri ve hava durumuna bağlı olayları anlamak için astronominin verilerinden yararlanmamiz gerekmektedir. Bacon, Batlamyus'un izinden giden Müslüman astronomların, geleceğe dair astrolojik yorumların genel bir eğilimin sonucu olarak ortaya çıktığını, ancak bunun bireysel eylemler için zorlayıcı bir unsur olarak kullanılmadığını belirterek, kendi kanaatinin de bu yönde olduğunu ifade etmektedir. ${ }^{66}$ Ancak Bacon, kişiden kişiye değişmekle birlikte bireyin fiillerinde, coğrafi ve astronomik özelliklerin etkili olabilme durumunun oldukça az olduğunu da beyan etmekten çekinmez.

Bacon'ın, astrolojik verileri Hristiyanlığı yüceltmek için kullandığını yukarıda beyan etmiştik. Onun bu beyanını temellendirdiği argümanda karşımıza şu unsurlar çıkmaktadır. Ona göre gökler on iki katmanlıdır. Bu katmanlar içinde yedi gezegen barındırmaktadır. Bu gezegenlerin her biri sembolik olarak bir dine karşıllık gelmektedir. Bu gezegenler içinde Jüpiter'in önemli ve özel bir anlamı vardır. Satürn Museviliği, Mars Keldaniliği, Venüs Müslümanlı̆̆ı (Serasenleri), Güneş Mısır dinini, Merkür ise Hıristiyanlığı temsil etmektedir. ${ }^{67}$ Merkür güçlü bir yapıya sahip olup (virgo/başak) sümbüle takımyıldızını bir işaret olarak almaktadır. Merkür

\footnotetext{
64 Bkz, Roger Bacon, The Opus Majus, Ed\&Int. J.H.Bridges, vol.I, s.180-183, 376

65 Roger Bacon, The Opus Majus, Ed\&Int. J.H.Bridges, vol.I,-s.210-219

66 Bkz, Roger Bacon, The Opus Majus, Ed\&Int. J.H.Bridges, vol.I, s.238-249

67 Roger Bacon, The Opus Majus, Ed\&Int. J.H.Bridges, vol.I, s.253-258
} 
Hıristiyanlığı temsil etmekle birlikte onun ayı da ondaki bozulmalara işaret etmektedir. Gezegenlerin ilişkileri özellikle de Jüpiter ve Satürn'e dair veriler tarihteki önemli devirleri aydınlatmaya yaramaktadır. Bunlar genellikle 20, 240 ve 960 yılda bir olan periyotlara işaret etmektedir. Bacon bu periyotlardan hareketle İslam'ın çok uzun süreli olamayacağını öngörmektedir. ${ }^{68}$ Merkür'ün işareti olan Virgo'nun ona göre karşılığı bakire Meryem'dir. Bunun yanında duygusallık ve şehvetin temsili olan Venüs ise İslam'1 temsil etmektedir. ${ }^{69}$ Ayrıca gökteki on iki katman ve yıldızlar tarih boyunca insanların günlük yaşamını düzenlemek ve geleceğe dair çıkarımlar yapmakta kullandığı burçlara dair yıldızları da göstermektedir. ${ }^{70}$ Düşünür her ne kadar astrolojik verilerin ve buna bağlı oluşturulan epistemolojinin güvenilir olmadığını beyan etse de, kendisi de buna dair bilgileri kullanmaktan geri kalmamıştır. Bundan dolayıdır ki, suçlanmasındaki en önemli dayanakların başında simya ve astrolojiye olan ilgisi gelmektedir.

\section{Kimya-Simya}

Bacon'ın en ilginç bilimsel yanlarından birisi de kuşkusuz simyaya ve onun doğal bir sonucu olan kimyaya duyduğu ilgidir. İlkçağdan beri insanlar değişmeyene olan ilgisinin bir sonucu olarak, adi metalleri değerli metaller haline, yani altın haline getirmek için uğraşmışlardır. Bu uğraşın bir sonucu olarak günümüzdeki gelişmiş kimya algısının oluşmasına önemli katkıları olan bu düşünürlerin insanlığa sağladığı diğer önemli bir katkı da, insanların sağlığına hizmet edecek çeşitli ilaç ve karışımları elde etmiş olmalarıdır. Düşünürün özellikle Compendium Philosophiae'de, Opus Tertium ve Opus Minus'da kimyaya dair görüşleriyle karşılaşmaktayız. Bunun dışında düşünüre nispet edilen pek çok irili ufaklı kimya ve simya ile ilgili çalışma bulunmaktadır. ${ }^{71}$ Onun mucit yanına dair en meşhur bilgilerden birisi olan barutun keşfiyle alakalı haberler, düşünürün kimya ile ilgili araştırmalarına işaret etmektedir. Her ne kadar

\footnotetext{
68 Roger Bacon, The Opus Majus, Ed\&Int. J.H.Bridges, vol.I, s.261-269

69 Bkz, Lynn Thorndike, "The True Roger Bacon II", The Amerikan Historical Reviev, vol. 21, Issue 3, s.472

70 Roger Bacon, The Opus Majus, Ed\&Int. J.H.Bridges, vol.I, 258-261

$71 \mathrm{Bkz}$, George Sarton, Introduction to the History of Science From Rabbi Ben Ezra to Roger Bacon, vol.II, s.958
} 
barutun keşfiyle ilgili haberlerin doğrulanmamış, efsanevi bir özelliği olsa da onun kimyaya olan ilgisini göstermesi bakımından dikkate değer bir bilgidir. Ancak Opus Tertium'da havai fişekle ilgili bir karışımdan bahsederken, barut olması muhtemel bir patlayıcıdan da bahsettiğine dair yorumlar yapılmaktadır. Onun kimya/simya ile ilgisinin en önemli göstergesi Compedium Philosophiae'nin dört bölümünün; Opus Tertium ve Opus Minus'un konuyla ilgili kısımların olmasıdır. ${ }^{72} \mathrm{O}$ kendisine aidiyeti şüpheli olan Speculum Alchimiae adlı risalede simyayı şu şekilde tarif etmektedir: Simya adına elixir (iksir/öz) dediğimiz bir tür ilaç yapma ya da üretmeyi öğreten bir sanat veya bilimdir. Bu ilimle metallere ve bedenlere nüfuz ederek onları tamir etme imkânı elde ederiz. Düşünür Opus Tertium'daki başka bir tanımı ise şöyledir. Mükemmel metaller ve renkler yapmayı öğreten simya teorik ve pratik olarak ikiye ayrılmaktadır. Bu diğer şeylerden (ilimlerden) daha iyi bereketli ve önemli bir ilimdir. ${ }^{73}$

Düşünürün simya ve kimya'ya olan ilgisi onun bazı ilaç denemeleri yapmaya kadar götürmüştür. Tıpkı astrolojik yaklaşımlarında olduğu gibi, ilaç yapımında da astrolojik bir yanın bulunduğunu iddia etmiştir. ${ }^{74} \mathrm{Bu}$ denemelerini yaparken, ilkçağ filozoflarından belki daha çok İbn Sina (Avicenna)'nın görüşlerden yararlanmıştı. Onun ilaçlara dair kaleme aldığı "De errobius medicorum" ve "De retandis senectutis accidentibus" adlı risaleler düşünürün bu hususa nasıl yaklaştığını göstermesi bakımından önemlidir. ${ }^{75}$ Bacon'ın simya/kimya ile olan ilgisinin en bilindik noktası, onun barutun keşfini yaptığı ya da bu keşfe öncülük ettiğine dair efsanevi haberdir.

\section{Coğrafya}

Opus Majus'un matematik kısmında astronomiyle beraber coğrafyanın önemine dair görüşlerle karşılaşmaktayız. Daha önce de beyan ettiğimiz gibi, düşünür dünyanın durumu ve iklimsel değişimlerle ilgili coğrafi bilgiler için astronominin verilerinden faydalanılması

$72 \mathrm{Bkz}$, George Sarton, Introduction to the History of Science From Rabbi Ben Ezra to Roger Bacon, vol.II, s.958

73 M.M. Pattison Muir, "Roger Bacon: His Relations to Alchemy and Chemistry," Roger Bacon Essays, s.292

74 Bkz, Roger Bacon, "Opus Tertium”, Opera Quædam Hactenus Inedia, I.Opus Tertium, II. Opus Minus, III.Compendium Philosophiæ, (içinde) Ed. J.S Brewer, s.99

$75 \mathrm{Bkz}, \mathrm{Bkz}$, George Sarton, Introduction to the History of Science From Rabbi Ben Ezra to Roger Bacon, vol.II,,s. 959; John Henry Bridges, The Life and Work of Roger Bacon, s.118-119 
gerektiğini düşünmekteydi. Bacon'ın coğrafya ile ilgili merakının gayesi, kuşkusuz ismini duyduğu, bazen hayranlık ve hayretle baktığı doğu dünyasına dair daha net bilgilere ulaşmaktı. Bundan dolayıdır ki, coğrafya konusunda gezginlerin bilgilerini önemsiyor ve yer yer bu bunlara referansta bulunuyordu. Bunlardan birisi de çağdaşı olan Flemenk asıllı, kendisi gibi Fransisken olan, misyoner ve gezgin William of Rubruquis'tir (ö.1293). O dünyanın güneyine dair görüşlerini Papa ile paylaşarak buraların alınmasını talep etmiş ve bunun için de bir harita hazırlamıştır. Söz konusu harita sonradan kaybolmuştur. Ancak bu haritanın belli başlı yerlerin koordinatlarını içerdiği söylenmektedir. Söz konusu haritada tıpkı Colombus gibi İspanya'dan sürekli batıya gidilerek Hindistan'a ulaşılacağı imkânından bahsedilmektedir. Peter of Ailly (ö. 1420) bu bilginin Colombus tarafından bilindiğini ve onu teşvik eden unsurlardan bir tanesi olduğunu ifade etmiştir. ${ }^{76}$

\section{Ahlak}

Bacon'ın düşünce sisteminde ayrıcalıklı bir yeri olan hususların başında ahlak kavramına yaklaşımı bulunur. Onun iyi bir bilim adamı ve ansiklopedist olmasında yatan en önemli etken kuşkusuz ahlak ilmine verdiği önemin yanında, ahlaklı olmayı bir yaşam ilkesi haline getirmeye çalışmasıdır. Onun ahlak anlayışı mensubu olduğu Hiristiyanlık dinini destekleyen ve bizatihi onun bir unsuru olan davranış ve hal durumudur. Ahlak'a dair ortaya koyduğu görüşlerin arka planında etkisinde kaldığ 1 Grek ve Hıristiyanlık öncesi düşünürlerin yanında, kendisinin de açıkça beyan ettiği gibi pek çok önemli Müslüman filozof ve düşünürün de etkisini gözlemleyebiliriz. ${ }^{77}$ Onun reformist bakış açısının içinde yer alan ahlakı, mensubu bulunduğu Katolikliği reforme etmek için önemli bir araç olarak görmekteydi. Ona göre Yahudilikten, Greklerden ve Müslümanlardan alınabilecek iyi ve kutsal şeyleri Hıristiyanlık altında birleştirebiliriz. Böylece daha manevi ve ahlaki bir yönetime/duruma kavuşabiliriz. ${ }^{78}$

Opus Majus'ta ahlak felsefesine dair müstakil bir bölüm ayırmasının yanında, ahlaklılık kavramı hem bu eserinde hem de diğer

76 Bkz, George Sarton, Introduction to the History of Science From Rabbi Ben Ezra to Roger Bacon, vol.II, s.958

77 John Henry Bridges, The Life and Work of Roger Bacon, s.125-126

78 John Henry Bridges, The Life and Work of Roger Bacon, s.127 
önemli eserlerinin çoğunda karşılaştığımız önemli vurgulardandır. Opus Majus'un başında insanın cehaletinin dört nedenini sayarken, değersiz otoriteye itaat, alışkanlıklarımıza bağlılı̆̆ımız ve popüler önyargılarımızın temelinde ahlaki bir yozlaşmanın olduğundan bahsetmektedir. ${ }^{79}$ Ona göre ahlak inanç sisteminin en önemli yap1 taşlarındandır. Bilgi ise inançtan sonra gelmektedir. İnancı ayakta tutan unsur ise ahlakl1lik durumudur. Ona göre erdemli insan cahilliğini bilen ve her zaman için öğrenmeye hazır insandır. ${ }^{80}$ Yukarıda da belirttiğimiz gibi onun ahlak anlayışında Aristo gibi ilkçağ filozoflarının paganist kabullerini taşımakta ve aynı zamanda Yahudiliğin de etkisini barındırmaktadır. Ona göre ünlü Müslüman düşünürler Farabi, İbn Sina ve Gazâlî’nin ahlaka dair görüşleri kendi çağdaşlarına göre oldukça toleranslı ve derin unsurlar barındırmaktadır. ${ }^{81}$ Düşünürün ahlaki vasfın yansıması olan erdemlere dair ortaya koyduğu hususlarda, büyük oranda Aristo'nun erdemler listesini bildiğini ve buna da sadık kaldığını söyleyebiliriz. Bacon bu bağlamda Aristo'ya bağlı olarak ortaya koymaya çalıştığı on iki erdemden bahseder. Bunların içinde klasik dört erdemin de olduğu, iffet, cesaret, hikmet, adalet, özgürlük, cömertlik, nezaket gibi erdemler vardır. ${ }^{82}$ Aristo'nun ünlü Etik eserine referansla erdemin ahlak veya iyi ahlaki davranış olarak tanımlar. Erdemlilik durumunu, kişinin ruhunun kurtuluşa ermek ve iyi bir toplum ve yaşam için kullanılabilecek en pratik yol olarak düşünmektedir.

Bacon'in Opus Majus'un ahlak felsefesi kisminda kendi zamanındaki belli başlı önemli inanç gruplarını sayarken inanç ve ahlaklılık durumunun önemine de değinmektedir. Bacon bu grupları altı kısımda ele almaktadır. Bunlar, Serasenler olarak isimlendirdiği Müslümanlar, Tatarlar olarak isimlendirdiği Moğollar, Paganlar, içinde Budistlerin de olduğu putperestler, Yahudiler ve Hıristiyanlar. ${ }^{83}$ Burada ilginç ve dikkate değer olan şey, düşünürün Asya'da meydana gelen siyasi gelişmelerin Avrupa'yı etkilemeye başlayacağına dair öngörüsüdür. Zira Moğollar İslam dünyasını yerle bir ederken, aynı zamanda Rusya'ya ve güney doğu Avrupa'ya doğru ilerliyor ve Batı krallıklarını da dolaylı olarak tehdit ediyordu. Papa

\footnotetext{
79 Bkz, Roger Bacon, The Opus Majus, Ed\&Int. J.H.Bridges, vol.I, s.2-4

80 Roger Bacon, The Opus Majus, Ed\&Int. J.H.Bridges, vol.I, s.21-23

81 John Henry Bridges, The Life and Work of Roger Bacon, s.32

82 Bkz, Roger Bacon, Opus Majus, trans, R.B.Burke, vol.II, s.665

83 Roger Bacon, Opus Majus, trans, R.B.Burke, vol.II, s.788
} 
IV. Innocent ve IX. Luis, Dominiken ve Fransisken keşişleri uzak doğuya göndererek, hem onları incelemek hem de misyonerlik imkânının olup olmadığına bakmak istemişlerdi. Buralara gönderilen Carpini ve Rubruquis gibi keşişlerin raporları hiç iç açıcı değildi. Bu gibi misyoner keşişler Doğu dünyasına dair pek çok önemli çalışma ve bilgiyi ${ }^{84}$ yazılı olarak Papalık makamına iletmiş ve ilerde yapılacak çalışmalara ön hazırlık yapmışlardır. Ona göre tehlike oldukça büyümüş, hem İslam dünyasını hem de Hıristiyan dünyayı etkileme pozisyonuna gelmişlerdi. İnançsızlar/putperestler Asya'nın pek çok yerinde etkili bir hâkimiyet kurmuşlardı. ${ }^{85}$ Papalık bu topluluklara misyonerler gönderip Hiristiyanlık propagandası yapmanın yanında, buralara ulaşan Müslümanlardan da aynı amaç için çalışanlar vard1.

\section{Etkileri ve Değerlendirme}

Roger Bacon, Hıristiyan dünyanın dogmatizminin en yoğun, skolastik düşüncenin en kuvvetli olduğu, aynı zamanda da bu zihinsel bakışın yavaş yavaş değişmeye ve kırılmaya başladığı bir dönem olan XIII. yüzyılda düşünce dünyamıza giren bir filozoftur. Oldukça meşhur olan çağdaşları St. Thomas ve Albertus Magnus'a kıyasla zorlu bir yaşam sürmüş ve kendi ekolünü oluşturamamış bir filozoftur. Hayatının neredeyse son yirmi yılın hapiste ve baskı içinde geçiren düşünürün eserleri, bu baskının ve kovuşturmanın sonucu olarak kendi döneminde ve vefatından belli bir süre geçene kadar insanların ilgisini pek çekmemiştir. Ancak Rönesans ve Reform hareketleriyle renklenen Avrupa düşüncesi, modernleşmeyle beraber bilimsel felsefenin kapılarını açtığında, kendilerine rehberlik edecek, idealist bir düşünür olarak Roger Bacon'ı ve düşüncelerinin farkına varmıştır. Hayatında görmediği itibar ve üne yüzyıllar sonra kavuşan Bacon, artık bilimsel düşüncenin adeta bir şövalyesi gibiydi. Onun hakkında yapılan çalışmalar sonrasında eserlerinin gözden geçirilerek yeniden neşredilmesi yirminci yüzyılın başında ilginin tekrar düşünürün üzerine yoğunlaşmasında etkili olmuştur. $\mathrm{Bu}$ ilginin sonucu olarak artık Bacon pek çok bilimsel başarının ya ilham kaynağı ya da başlatıcısı olarak bilim felsefesinin en önemli filozoflarından biri olarak kabul edilmektedir. Bu kabulün oluşma-

84 Bkz, Roger Bacon, Opus Majus, trans, R.B.Burke, vol.II, s. 789

85 John Henry Bridges, The Life and Work of Roger Bacon, s.134 
sında ise düşünürün doğrudan ve dolaylı olarak katkı yaptığı hususları şöyle bir özetlediğimizde şu hususların ön plana çıktığını söyleyebiliriz.

Her şeyden öte Bacon'un Yeniçağ ve sonrasında sıkça karşılaştığımız türden bilimsel keşifler yapan bir mucit olmadığını, ancak bilim çalışmalarının pratik olarak kullanılması gereğini ortaya koyup, bunu deneyen bir düşünür olduğunu bilmemiz gerekir. Ona atfedilen pek çok icadın mucidi olmasa da, çağdaşı olan ünlü misyoner seyyah William of Rubruck'un Moğollarla olan münasebetinden aktardığg bilgileri kullanarak barutun Avrupa'da ilk defa kullanılmasına öncülük ettiğini söyleyebiliriz. Opus Majus'ta havai fişek yapımıyla ilgili bazı karışımlardan bahsetmesine rağmen, barut yapımına dair net bir ifade bulunmamaktadır. Ancak onun barutun mucidi olduğuna dair yaygın kanaat halen canlılı̆̆ını korumaktadir. 86

Düşünürün takvime dair yaptığı çalışmalar kendisinden yaklaşık üç yüz yıl sonra, İngiltere'de astronom John Dee (ö.1608) tarafından 1582'de takvimde yapılacak reform çalışması için Kraliçe Elizabeth'e sunulan öneride referans olarak Bacon gösterilmiştir. Optik üzerine yaptığ çalışmalarda, kendisinin etkilendiği İbn Heysem'den farklı olarak bazı pratik sonuçlar üzerinde denemeleri olmuştur. Özellikle lensler üzerine yaptığı çalışmaların daha sonra mikroskop ve teleskop yapımında önemli katkıları sağlamıştır. Optik deneyleri için, kendi zamanına göre oldukça önemli paralar harcamış olan düşünür, kendi çalışmalarına katkıda bulunması için Papa'ya kendi yaptığ lenslerden birini göndermiştir. Bilimin pratik alanda kullanılmasına öncülük etmesi bakımından Bacon'ın bilim tarihinde önemli bir yeri olduğu aşikârdır. Onun optik çalışmaları daha sonraları John Peckham, William of Saint Cloud (ö.1320'den önce) ve Leonard Digges gibi araştırmacıları etkilemiştir. ${ }^{87}$ Onun bu alandaki etkilerini tıpkı baruta dair karşımıza çıkan bilgilerde olduğu gibi, sonraları kendisinin mikroskop ve teleskopun mucidi olduğuna kadar genişletenler olmuştur. ${ }^{88}$

86

87

88

\footnotetext{
tium, II. Opus Minus, III.Compendium Philosophix, (içinde) Ed. J.S Brewer, s.111; George Sarton, Introduction to the History of Science From Rabbi Ben Ezra to Roger Bacon, vol.II, s.957

Arnold Pacey, Technology in World Civiliztion, Mit Press, Cambridge-1991, s.45 Bkz, Roger Bacon, “Opus Tertium”, Opera Quædam Hactenus Inedia, I.Opus TerBkz, John Henry Bridges, The Life and Work of Roger Bacon s.105
} 
Bacon'ın en önemli etkilerinden birisi kuşkusuz klasik dillere verdiği önemin daha sonraları Avrupa üniversitelerinde yayılmış olmasıdır. Papa V. Clement zamanında 1312 yılında Viyana Konsilinde, İbranice, Grekçe, Keldanice ve Arapça dillerine dair kürsülerin Avrupa'nın kadim üniversiteleri olan Roma, Paris, Oxford, Bologna ve Salamanca gibi üniversitelerde kurulması için tavsiye kararı alınmıştır. ${ }^{89}$ Bu karar, bazı üniversitelerde belli oranda uygulanmasına rağmen tam olarak başarılı olmasa da, artık bu dillerin daha etkili bir şekilde düşünce dünyasında kullanılmasında tesiri olduğu kesindir.

Opus Majus'un dördüncü kısmını tamamen tecrübi ilimlere ayıran Roger Bacon aslında bir anlamda düşünce ve pratik açıdan, kendinden dört yüzyıl sonra gelecek olan Francis Bacon'1 (ö.1626) ve onun meşhur eseri Novum Organum'u öncelemektedir. ${ }^{90}$ Ölümünden yüzyıllar sonra eserlerinin basılması ona olan hayranlığı zaman zaman efsanevi boyutlara taşımıştır. Özellikle Robert Greene'in (ö.1592) Bacon'ın hakkında yazdığı oyun, düşünürü bilimsel düşüncenin sembolü haline getirmiştir. ${ }^{91}$ Onun kısıtlı imkânlarla kendisinden sonra gelen nesilleri aydınlatacak olan vizyoner bakışı, yapılan her keşifte onun izlerinin olduğu hissinin doğmasına neden olmuştur. Onun öngörüleri modern dünyanın başlangıcını yüzyıllar öncesinden haber vermektedir. Bu nedenle o kendine has bir düşünür olarak görülüp, modern bilimin öncüsü olarak kabul edilmiştir. ${ }^{92}$

89 A.G. Little, “Introduction: On Roger Bacon's Life and Works", Roger Bacon Essays, s. 29

90 Frederic Harrison, Friar Roger Bacon, "The North American Review, Vol. 202, 1915 , s.245

91 Bkz, Robert Greene, Friar Bacon and Friar Bungay, ed. Daniel Seltzer, University of Nebraska Press, 1963.

$92 \mathrm{Bkz}$; George Sarton, Introduction to the History of Science From Rabbi Ben Ezra to Roger Bacon, vol.II, s.962; Frederick Mayer, A History of Educational Thought, Charles E. Merrill Books, Ohio-1966, s.500-501; Onun modern bilimlerin öncüsü olma durumunu, ontik bir düzeyde önemli sayan Harrison, onu gerçek bir bilim şehidi olarak kabul etmiştir. Kendisinden sonra gelen Francis Bacon, Descartes ve Leibniz' den daha kapsamlı bir düşünür olarak kabul ederek onu oldukça idealize edilmiş bir şahsiyet olarak sunmuştur. Bkz, Frederic Harrison, Friar Roger Bacon, s.244 
Bacon, XIII. yüzyılın iki ünlü ilim merkezi olan Paris ve Oxford'da bulunmuş, buradaki üniversitelerde Aristo mantığ 1 haricinde de dersler vermiştir. Bu dersleri veren ilk düşünürlerden olması, hocası Grosseteste'nin yarım bıraktığı tecrübi ilimlere dair çalışmaları pratik olarak uygulamaya çalışması ve dil ve müfredata dair ortaya koyduğu görüşleri hararetle savunması bakımından çağdaşlarından farklılaşır. ${ }^{93}$ Klasik dünyaya düşkünlüğünün bir gereği olarak yücelttiği pek çok Grek ve Müslüman düşünürün yanında, çağdaşı olduğu Alexander Hales, Albertus Magnus ve St. Thomas gibi dogmatik dünyanın önemli ve kabul görmüş düşünürleriyle uzlaşamamış, onlara zaman zaman istihzaya varan eleştiriler yöneltmiştir. Hatta bir keresinde Albertus Magnus'un, Aristo, İbn Sina ve İbn Rüşd ile eşdeğermiş gibi görülüp, yüceltilmesine şiddetle karşı çıkmış, "böyle bir canavarlığın dünyada daha önce olmadığını" ifade edecek kadar Magnus'a olan tavrını ortaya koymuştur. ${ }^{94}$ Onun çağdaşlarından farkı ise metot olarak tecrübi ilimlere, eşyanın bilgisine dair ısrarıdır. Ona göre Albertus Magnus ve St. Thomas öğrenmenden öğretmen olmuş kişiler gibidirler. St. Thomas Grekçe anlamamasına, matematik ve fizik bilgisine sahip olmamasına rağmen, Aristo hakkında kalın ciltler doldurmuştur. ${ }^{95}$

Bacon'ın çağdaşlarına oranla ortaya koyduğu vizyon oldukça dikkate değer olmasına rağmen, sonrasında kendisini izleyen bir ekolünün olmaması onun hakkındaki bilgilerin çok sonrasında yeniden inşa edilmesine neden olmuştur. Onun ileri görüşlülügüu, ansiklopedist tavrının yanında, bilim adamlılığı hususunda çok iddialı bir kişilik olduğunu söylemek zordur. O hiçbir zaman iyi bir matematikçi, kimyacı, ya da herhangi bir alanda teorisyen olarak kabul edilmemiştir. Ancak onun öngörülerinin sonraki gelişmelere ilham kaynağı olmuş olması ve çağlar öncesinden buna cesaret göstermesi bakımından kendisine verilen "Doktor Mirabilis" lakabını sonuna kadar hak etmiştir. Düşünce tarihi, onu bizatihi üreten ve katkıda bulunan düşünürlerin toplamından ibarettir. Bacon da modernleş-

$93 \quad$ Frederic Harrison, Friar Roger Bacon, s.247

94 Bkz, Jeremiah Hackett, "Roger Bacon on the Classification of the Sciences" , Bacon \& the Sciences, s.49, Stewart C. Easton, Roger Bacon and His Search for a

Uniersal Science, , s.210-219

95 Karl Vorlander, Felsefe Tarihi, s.296 
meyle başlayan bilimsel felsefeye üretimleriyle olmasa bile, yüzyıllar öncesinden vizyonerliği ve cesaretiyle katkıda bulunmuş bir düşünür olarak düşünce tarihindeki yerini almıştır.

\section{Kaynakça}

Bacon, Roger, Compendium Studii Theologiae, ed. H.Rashdall, British Society of Franciscan Studies, Vol.III, London-1911.

Bacon, Roger, Opera Hactenus Inedita Rogeri Bacon, Fas. 15, Summa Grammatica Magistri Rogeri Bacon; Necnon Sumule Dialectices Magistri Rogeri Bacon, ed. Robert Steele, London-1940.

Bacon, Roger, Opera Hactenus Inedita Rogeri Baconi, Fas.V: Secretum Secretorum Cum Glossis Et Notulis, ed. Robert Steele. Oxford University Press, Oxford-1920.

Bacon, Roger, Opera Quædam Hactenus Inedia, I.Opus Tertium, II. Opus Minus, III.Compendium Philosophiæ, Ed. J.S Brewer, London-1859.

Bacon, Roger, Opus Majus, trans, R.B.Burke, vol.I-II, Russell\&Russell, New York-1962.

Bacon, Roger, Roger Bacon and the Origins of "Pespectiva" in the Middle Ages: A Critical Edition and English Translation of Bacon's Pespectiva with Introduction and Notes, trans\&not: David C. Lindberg, Oxford University Press, Oxford-1996.

Bacon, Roger, The Greek Grammar of Roger Bacon and a Fragment of His Hebrew Grammar, Cambridge University Press, Cambridge-1902.

Bacon, Roger, The Opus Majus, Ed\&Int. J.H.Bridges, vol.I,-II-III Williams and Norgate, Oxford-1897-1900.

Brewer, J.S., "Preface", Opera Quædam Hactenus Inedia, I.Opus Tertium, II. Opus Minus, III.Compendium Philosophiæ, (içinde) Ed. J.S Brewer, London-1859.

Bridges, John Henry, The Life and Work of Roger Bacon, William and Norgate, London-1914.

Brown, Stephen F., Flores, Juan Carlos, Historical Dictionary of Medieval Philosophy and Theology, Plymouth-2007.

Duncan, David Ewing, The Calendar, Avon Books, London-1998.

Easton, Stewart C., Roger Bacon and His Search for A Universal Science, Colombia University Press, Newyork-1952.

Greene, Robert, Friar Bacon and Friar Bungay, ed. Daniel Seltzer, University of Nebraska Press, 1963,

Hackett, Jeremiah, "Roger Bacon on the Classification of the Sciences" Roger BaconEthe Sciences, , ed. Jeremiah Hackett, Brill-1997,

Harrison, Frederic, "Friar Roger Bacon", The North American Review, Vol. 202, 1915. 
Lemay, Richard, "Roger Bacon's Attitude Toward the Latin Translations and Translators of the Twelfh and Thirtenth Centuries", Roger Bacon\&the Sciences, ed. Jeremiah Hackett, Brill-1997.

Little, A.G., "Introduction: On Roger Bacon's Life and Works", Roger Bacon Essays, Ed. A.G. Little, Oxford University Press, Oxford-1914.

Little, A.G., "Roger Bacon's Works with References to the Mss. and Printed Editions", Roger Bacon Essays Ed. A.G. Little, Oxford University Press, Oxford-1914.

Mayer, Frederick, A History of Educational Thought, Charles E. Merrill Books, Ohio-1966.

Molland, George, "Roger Bacon's Knowledge of Mathematics", Roger BaconEthe Sciences, ed. Jeremiah Hackett, Brill-1997.

Pacey, Arnold, Technology in World Civiliztion, Mit Press, Cambridge-1991.

Pattison, M.M. Muir, Roger Bacon: "His Relations to Alchemy and Chemistry", Roger Bacon Essays, Ed. A.G. Little, Oxford University Press, Oxford-1914.

Sarton, George, Introduction to the History of Science From Rabbi Ben Ezra to Roger Bacon, vol.II, New York-1975.

Sinkler, Georgette, "Roger Bacon”, Routledge Encyclopedia of Philosophy, General Ed. Edward Craig, vol.1, Routledge, New York, 1998.

Smith, A.Mark, "Ptolemy's Theory of Visial Perception: an English Translation of The Optics with Introduction and Commentary", The American Philosophical Society, vol:86, part:2 Philedelphia-1996.

Smith, David Eugene, "The Place of Roger Bacon in The History of Mathematics", Roger Bacon Essays Ed. A.G. Little, Oxford University Press, Oxford-1914.

The Oxford Companion to Philosophy, Oxford University Press, ed. Ted Honderich, 2005-Oxford.

Thorndike, Lynn, "The True Roger Bacon II", The Amerikan Historical Reviev, Vol. 21, Issue 3, 1916.

Vorlander, Karl, Felsefe Tarihi, çev: Mehmet İzzet, Orhan Saaddettin, sad.Yüksel Kanar, İz Yayıncılık, İstanbul-2004.

Williams, Stewen J., "Roger Bacon and His Edition of the Pseudo-Aristotelian Secretum Secretorum", Mediavel Academy of America, vol.69, no:1, 1994.

Wolter, Allan B., "Roger Bacon", The Encyclopedia of Philosohpy, Macmillian Publishing, vol. 1-2, Londra-1972. 


\section{MILEL VE NIHAL}

inanç, kültür ve mitoloji araştırmaları dergisi

Cilt/Volume: 11 Sayı/Number: 2 Temmuz - Aralık / July - December 2014

ISSN: 1304-5482

Bu dergi uluslararası EBSCO HOST Research Databases veri indeksi ve

TÜBITAK-ULAKBİM Sosyal ve Beşeri Bilimler Veri Tabanı tarafından taranmaktadır.

\section{Sahibi / Owner}

Milel ve Nihal Eğitim, Kültür ve Düşünce Platformu Derneği adına Şinasi Gündüz

$$
\begin{aligned}
& \text { Yazı İşleri Sorumlusu / Legal Representative } \\
& \text { Yasin Aktay }
\end{aligned}
$$

Editör / Editor

Şinasi Gündüz

Editör Yrd. / Co-Editor

Cengiz Batuk

Hakan Olgun

\section{Yayın Kurulu/ Editorial Board*}

Alpaslan Açıkgenç, Ayaz Akkoyun, Yasin Aktay, Mahmut Aydın,

Cengiz Batuk, Şinasi Gündüz, İbrahim Kayan, Hakan Olgun, Necdet Subaşı,

\section{Burhanettin Tatar}

\section{Danışma Kurulu/Advisory Board*}

Baki Adam (Prof. Dr., AÜ); Mohd. Mumtaz Ali (Prof. International Islamic U. Malezya); Adnan Aslan (Prof.Dr., Süleyman Şah Ü.); Kemal Ataman (Doç.Dr., Uludağ Ü.); Mehmet Akif Aydın (Prof. Dr., Marmara Ü.); Yılmaz Can (Prof. Dr., OMÜ); Ahmet Çakır (Doç. Dr., OMÜ); Mehmet Çelik

(Prof. Dr., Celal Bayar Ü.); Waleck S. Dalpour (Prof. University of Maine at Farmington); İsmail

Engin (Dr., Berlin); Cemalettin Erdemci (Prof.Dr. YYÜ); Tahsin Görgün (Prof.Dr., 29

Mayıs Ü.) Ahmet Güç (Prof.Dr., Uludağ Ü.); Recep Gün (Doç. Dr., OMÜ); Ö. Faruk Harman

(Prof.Dr., Mar.Ü.); Erica C.D. Hunter (Dr., Cambridge U.); Mehmet Katar (Prof. Dr., A.Ü.);

Mahmut Kaya (Prof. Dr., İ.Ü.); Sadık Kılıç (Prof.Dr., Atatürk Ü.); Şevket Kotan (Y.Doç.Dr., İ.Ü.); İlhan Kutluer (Prof.Dr., Mar. Ü.); George F. McLean (Prof. Catholic Univ., Washington DC); Ahmet Yaşar Ocak (Prof. Dr., Hacettepe Ü.); Jon Oplinger (Prof. University of Maine at Farmington); Ömer Özsoy (Prof.Dr., Frankfurt U.); Roselie Helena de Souza Pereira (Mestre em

Filofia-USP; UNICAMP Brasil); Ekrem Sarıkçıŏlu (Prof.Dr., SDÜ); Hüseyin Sarıoğlu (Prof.Dr.,

İÜ); Bobby S. Sayyid (Dr. Leeds U.); Mustafa Sinanoğlu (Prof.Dr., 29 Mayıs Ü.); Mahfuz Söylemez

(Prof.Dr. IÜ); Necdet Subaşı (Y.Doç.Dr., DİB); Bülent Şenay (Prof.Dr., UÜ); İsmail Taşpınar

(Prof.Dr. Mar.Ü.); C. Sadık Yaran (Prof.Dr., OMÜ); Ali Murat Yel (Prof.Dr., Fatih Ü.); Hüseyin Yılmaz (Doç.Dr., YYÜ); Ali İhsan Yitik (Prof. Dr., DEÜ)

* Soyadına göre alfabetik sıra / In alphabetical order

\section{Kapak ve Sayfa Tasarımı / Cover \& Page Design} İnan Avc1

Baskı / Publication

Ladin Ofset - İstanbul, Haziran 2015

2.Mat. Sit. 3 NB 15 Topkapi İstanbul / İsmail Tüz 02125012418

Yönetim Yeri / Administration Place

Milel ve Nihal Eğitim, Kültür ve Düşünce Platformu Derneği

Fevzipaşa Cad. Şehit Mehmet Sarper Alus Sok. No: 5, K.: 3, Tel: (0212) 5339731 Fatih/İstanbul www.milelvenihal.org e-posta: dergi@milelvenihal.org

Milel ve Nihal yılda iki sayı olarak altı ayda bir yayımlanan uluslararası hakemli bir dergidir. Milel ve Nihal' de yayımlanan yazıların bilimsel ve hukuki sorumluluğu yazarlarına aittir. Yayım dili Türkçe ve İngilizce'dir. Yayımlanan yazıların bütün yayın hakları Milel ve Nihal'e ait olup, yayıncının izni olmadan kısmen veya tamamen basılamaz, çoğaltılamaz ve elektronik ortama taşınamaz. Yazıların yayımlanıp yayımlanmamasından yayin kurulu sorumludur. 


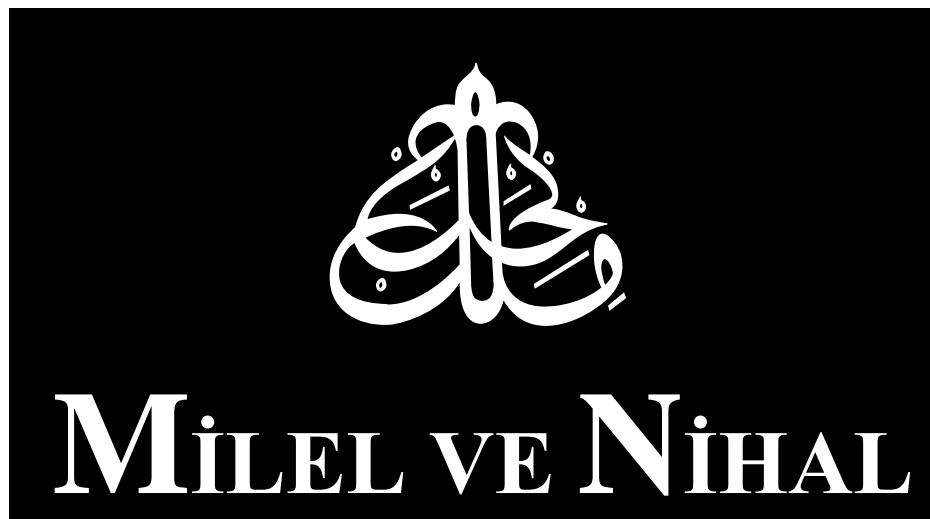

inanç, kültür ve mitoloji araştırmaları derogisi

ISSN: 1304-5482

Cilt/Volume: 11 Sayı/Number: 2

Temmuz - Aralık / J uly - December 2014 


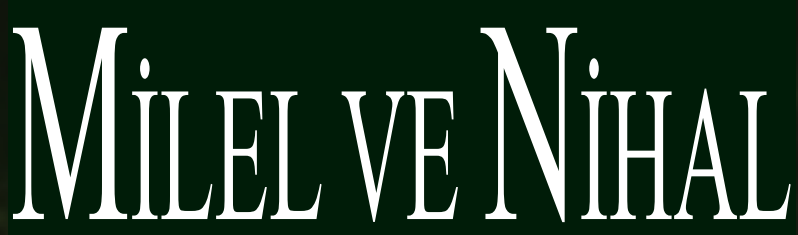

inanç, kültür ve mitoloji araştırmaları dergisi

ISSN 1304-5482

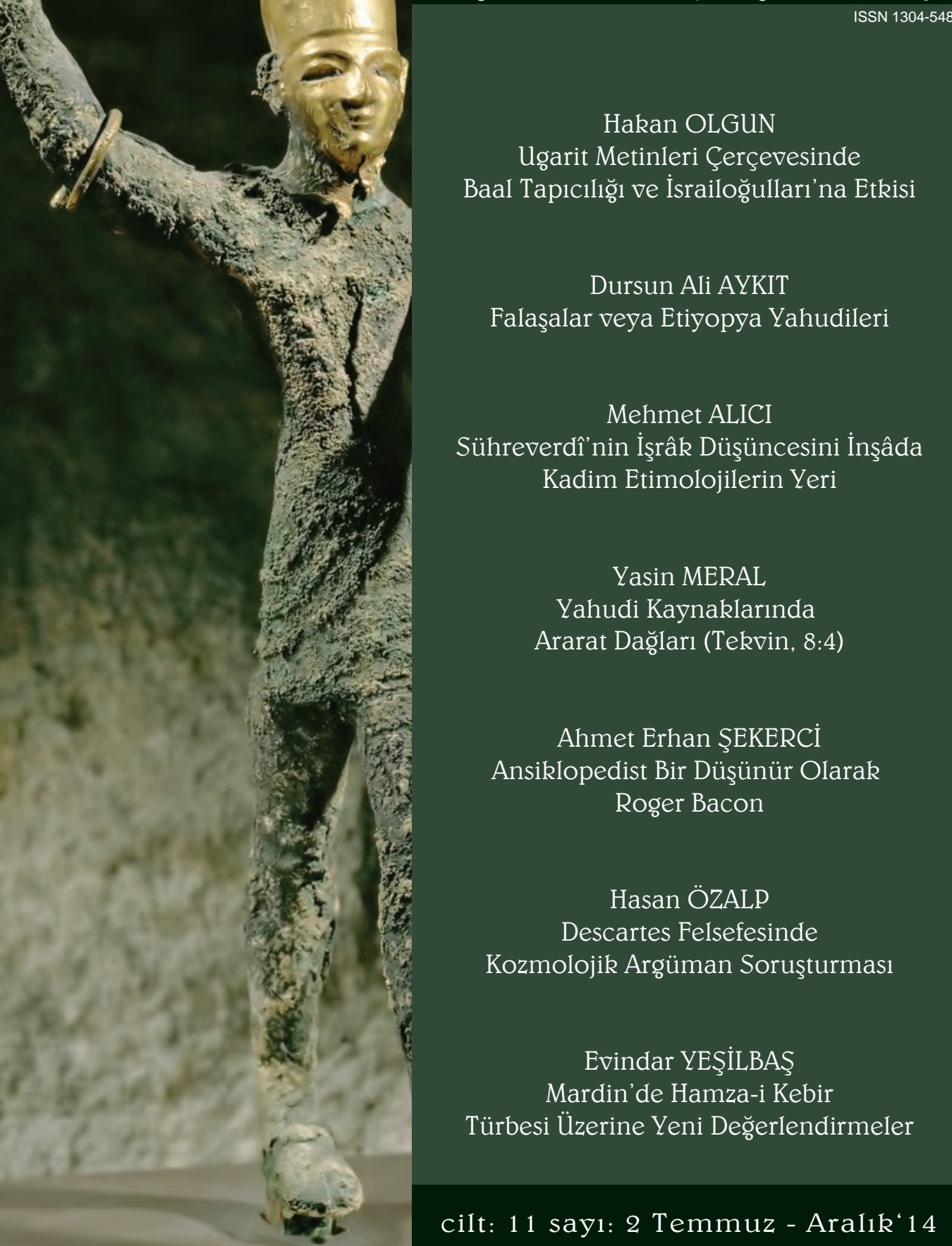

